\title{
ANALISIS KERUNTUHAN BENDUNGAN (DAM BREAK ANALYSIS) DALAM UPAYA MITIGASI BENCANA (STUDI KASUS DI WADUK/ BENDUNGAN TEMPURAN)
}

\author{
Oleh: \\ Muhamad Arifin ${ }^{1}$, Muchamad Arif Budiyanto ${ }^{2}$ \\ E-mail: nifira.arkana@gmail.com¹, arifbudiyanto.sipil@gmail.com²
}

\begin{abstract}
ABSTRAK: Bendungan Tempuran disamping bermanfaat untuk memenuhi berbagai kebutuhan bagi manusia, juga menyimpan potensi bahaya yang sangat besar bila tidak dikelola dengan baik, yaitu apabila bendungan tersebut runtuh dapat menyebabkan kerugian jiwa dan materi yang sangat besar, serta hancurnya infrastruktur yang ada di daerah hilirnya. Salah satu potensi bahaya yang dapat ditimbulkan adalah keruntuhan Bendungan. Keruntuhan dapat diakibatkan oleh bocoran yang membawa material bendungan secara berangsur-angsur yang disebut erosi buluh atau piping. Akibat keruntuhan tersebut, air yang tertampung di bendungan akan mengalir ke lembah sungai di hilir bendungan dengan debit yang sangat besar serta kecepatan aliran air banjir yang sangat tinggi. Untuk meminimalkan kerugian yang dapat ditimbulkan akibat keruntuhan bendungan, maka perlu dilakukan mitigasi bencana dalam rangka melakukan upaya tindakan preventif dengan cara melakukan simulasi pemodelan keruntuhan Bendungan.
\end{abstract}

Analisis keruntuhan Bendungan Tempuran (dam break analysis) dilakukan dengan pemodelan menggunakan bantuan software Zhong Xing HY21 dengan skenario kondisi muka air waduk setinggi banjir desain, dimana inflow hidrograf sama dengan banjir rencana. Kondisi dalam analisis keruntuhan bendungan tersebut ditinjau dalam alternatif kondisi akibat piping atas pada elevasi \pm 123 $m$ dengan inflow PMF (probably maximum flood). Kondisi ini diasumsikan merupakan kondisi yang paling optimal sebagai acuan untuk melakukan Tindakan rencana mitigasi bencana dalam upaya meminimalkan kerugian baik kerugian materiil maupun kerugian imateriil

Dari hasil analisis pemodelan tersebut dengan scenario piping atas dan dari hasil analisis hidrologi dengan debit inflow PMF (Snyder) sebesar 137,257 $\mathrm{m}^{3} /$ det diperoleh hasil dampak banjir yang ditimbulkan sepanjang 9,911 km kearah hilir melalui aliran Sungai Ngampel yang bermuara di Sungai Lusi. Area terdampak meliputi 15 Desa di dua Kecamatan sepanjang sungai tersebut yang berada di hilir dari Bendungan Tempuran. Waktu tiba banjir ke desa terdekat (Desa Tempuran) adalah 15 menit sedangkan waktu banjir sampai ke desa terjauh (Desa kamolan) adalah 6 jam.

Keyword/Kata Kunci: Banjir Rancangan, Bendungan, Keruntuhan, Mitigasi.

\section{PENDAHULUAN}

Bendungan Tempuran, disamping bermanfaat untuk memenuhi berbagai kebutuhan bagi manusia, juga menyimpan potensi bahaya yang sangat besar bila tidak dikelola dengan baik, yaitu apabila bendungan tersebut runtuh akan menyebabkan kerugian jiwa dan materi, serta hancurnya infrastruktur yang ada di daerah hilirnya. Adanya Pembangunan suatu bendungan seringkali diikuti dengan perkembangan masyarakat di daerah hilirnya, hal tersebut menyebabkan semakin bertambahnya tingkat bahaya keruntuhan bendungan. Keruntuhan bendungan dapat diakibatkan oleh overtopping dimana air yang melimpas melalui puncak bendungan menyebabkan terjadinya erosi serta longsoran pada tubuh bendungan, khususnya pada bendungan tipe urugan.

Keruntuhan dapat juga diakibatkan oleh bocoran yang membawa material bendungan secara berangsur-angsur yang disebut erosi buluh atau piping. Akibat keruntuhan tersebut, air yang tertampung di bendungan akan mengalir ke lembah sungai di hilir bendungan dengan debit yang sangat besar serta kecepatan aliran air banjir yang sangat tinggi. Bila kapasitas alur sungai tidak dapat menampung debit air banjir tersebut, maka air akan meluap keluar dari alur sungai dan menggenangi daerah pemukiman maupun lahan pertanian di sepanjang kanan kiri alur sungai.

27 Analisis Keruntuhan Bendungan (DAM Break Analysis) Dalam Upaya Mitigasi Bencana (Studi Kasus di Waduk/Bendungan Tempuran (Muhamad Arifin, Muchamad Arif Budiyanto) 


\section{1,2) adalah staf pengajar Program Studi Teknik Sipil Universitas Cokroaminoto Yogyakarta}

Mengingat adanya kemungkinan terjadinya malapetaka yang diakibatkan oleh runtuhnya suatu bendungan terhadap kondisi yang ada di hilir bendungan, dimana antara lain terdapat daerah permukiman yang cukup padat penduduknya dan/atau daerah industri serta berbagai bangunan fasilitas umum lainnya seperti jembatan, jalan raya dan lain-lain, maka perlu dilakukan analisis terhadap kondisi hidrolis alur dan lembah sungai di hilir (downstream valley) bendungan, khususnya apabila bendungan tersebut runtuh.

Tujuan dari penelitian ini adalah untuk mengetahui sampai sejauh mana dampak yang ditimbulkan akibat dari keruntuhan Bendungan Tempuran meliputi :

a. Dampak genangan yang ditimbulkan akibat keruntuhan Bendungan Tempuran

b. Wilayah terdampak dalam lingkup desa dan kecamatan akibat keruntuhan bendungan

c. Waktu tempuh banjir dari masing-masing wilayah terdampak

d. Penanganan dalam rangka upaya mitigasi bencana dalam rangka meminimalisasi kerugian baik material maupun immaterial.

\section{TINJAUAN PUSTAKA}

\subsection{Bendungan Tipe Urugan}

Menurut Suyono (1977) suatu bendungan yang dibangun dengan menimbun bahan-bahan seperti batu, kerakal, kerikil, pasir, dan tanah dengan komposisi tertentu dengan fungsi sebagai pengempang atau pengangkat permukaan air yang terdapat di dalam waduk di hulunya disebut bendungan tipe urugan atau "bendungan urugan". Berdasarkan ukuran butiran dari bahan timbunan yang digunakan, secara umum bendungan urugan dapat dibedakan menjadi 2 tipe yaitu :

1. Bendungan urugan batu (rock fill dam) disingkat dengan istilah bendungan batu

2. Bendungan urugan tanah (earth fill dam) disingkat dengan istilah bendungan tanah

Selain dari kedua jenis bendungan tersebut, terdapat pula bendungan urugan campuran yaitu terdiri dari timbunan batu di bagian hilirnya yang berfungsi sebagai penyangga, sedangkan di bagian hulunya merupakan timbunan tanah yang disamping berfungsi sebagai penyangga tambahan, terutama berfungsi sebagai penutup kedap air.

\subsection{Klasifikasi Bendungan Urugan}

Sesuai dengan fungsinya sebagai penampung dan peninggi muka air di dalam tampungan waduk, maka fungsi utama dari tubuh bendungan merupakan penahan rembesan air ke arah hilir serta penyangga dari tampungan/ kom dari waduk tersebut.

Jika ditinjau dari penempatan serta susunan bahan yang membentuk tubuh bendungan, maka bendungan urugan dapat digolongkan dalam 3 tipe utama yaitu :

1. Bendungan urugan homogen (bendungan homogen)

Bendungan urugan digolongkan dalam bendungan homogen apabila bahan bahan yang membentuk tubuh bendungan tersebut terdiri dari tanah yang hamper sejenis dan gradasinya (susunan ukuran butirannya) hamper seragam.

2. Bendungan urugan zonal (bendungan zonal)

Bendungan urugan digolongkan dalam bendungan zonal apabila timbunan yang membentuk tubuh bendunganterdiri dari batuan dengan gradasi (susunan ukuran butiran) yang berbeda-beda dalam urutan-urutan lapisan tertentu.

3. Bendungan urugan bersekat (bendungan sekat)

Bendungan urugan digolongkan dalam bendungan sekat apabila bahan pembentuk tubuh bendungan terdiri dari bahan yang lolos air, tetapi di lengkapi dengan dinding yang tidak lolos air di bagian lereng hulunya, yang biasanya terbuat dari lembaran baja tahan karat, beton bertulang, aspal beton, plastic, dll. 

di bawah ini.

Untuk lebih jelasnya secara detail tipe bendungan dapat dilihat dalam gambar 1.1

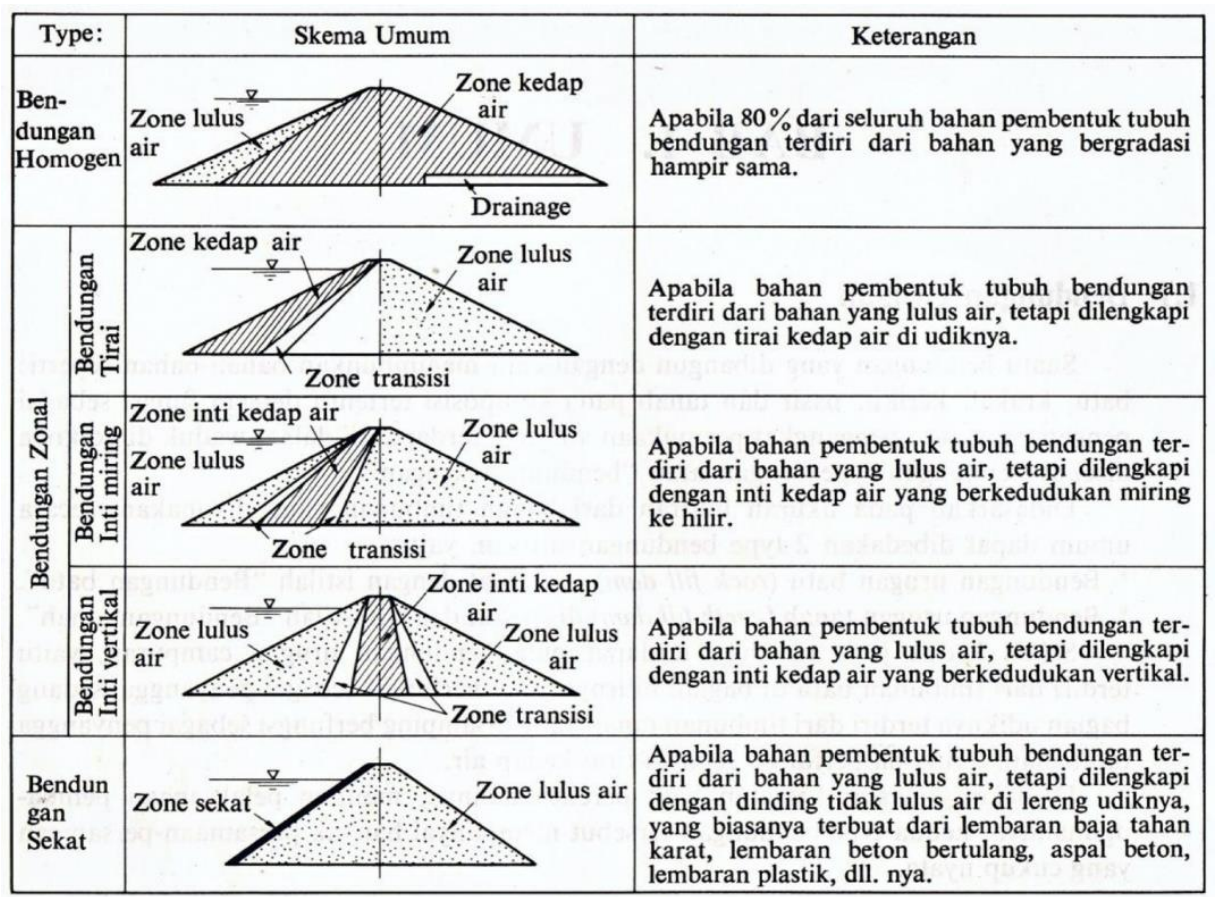

Gambar 1. Klasifikasi Bendungan Urugan (sumber Suyono, 1977)

\subsection{Hujan dan Aliran}

Prosedur perencanaan pemanfaatan sumber daya air kerap kali memerlukan nilainilai laju hujan, tebal hujan, dan karakter aliran. Karakter aliran yang perlu diketahui sangat berkaitan dengan sasaran pemanfaatan air. Seringkali hanya debit puncak yang digunakan untuk debit perencanaan, tetapi tidak jarang pula besarnya aliran dari waktu ke waktu perlu dianalisa untuk perencanaan penyediaan air bagi suatu keperluan (Sudjarwadi, 1988).

Proses pembentukan hujan dapat terjadi akibat tersedianya udara lembab, tersedia sarana, keadaan yang dapat mengangkat uap air tersebut keatas sehingga terjadi kondensasi. Udara lembab biasanya terjadi karena adanya gerakan udara mendatar, khususnya yang berasal dari atas lautan. Terjadinya pembentukan awan tidak selalu memungkinkan terjadinya hujan, diperlukan waktu sampai awan tersebut terbentuk menjadi awan hujan (Sri Harto, 1993).

29 Analisis Keruntuhan Bendungan (DAM Break Analysis) Dalam Upaya Mitigasi Bencana (Studi Kasus di Waduk/Bendungan Tempuran (Muhamad Arifin, Muchamad Arif Budiyanto) 


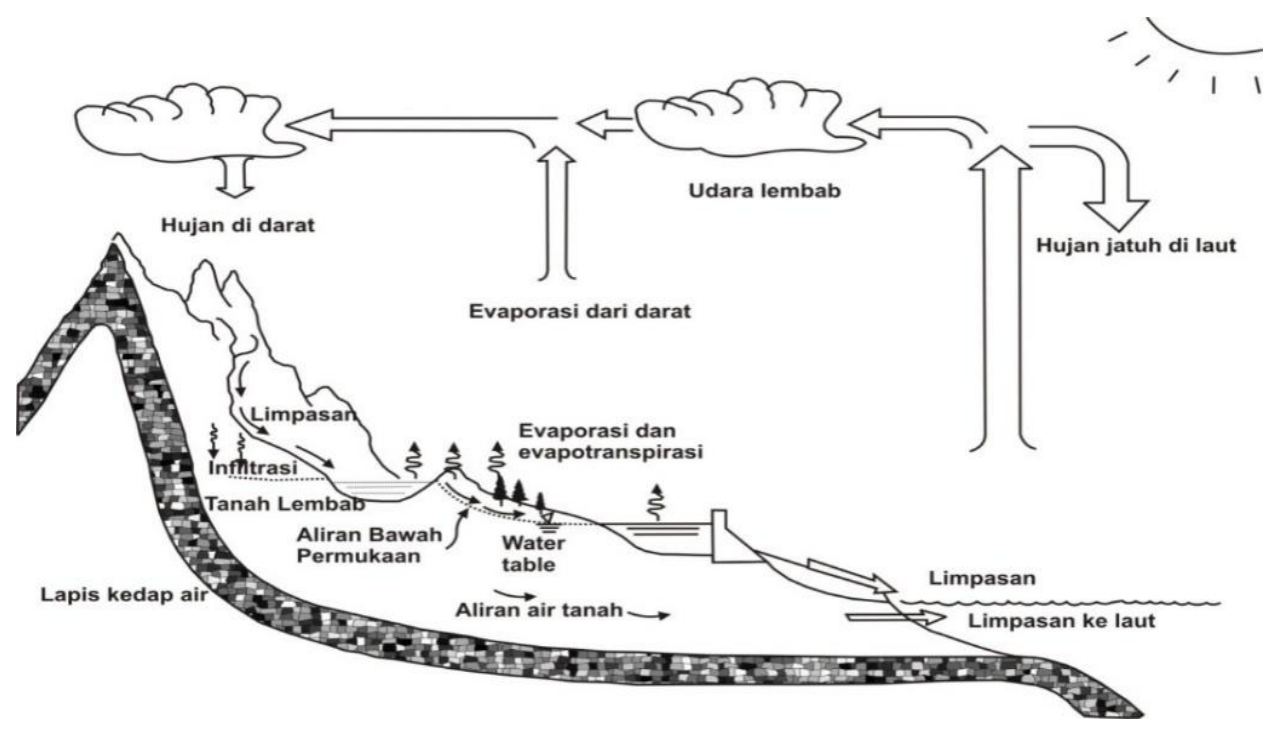

Gambar 2. Siklus Hidrologi (sumber : Triatmojo, 2008)

\section{LANDASAN TEORI}

\subsection{Analisis Hidrologi}

Analisis hidrologi yang akan dilakukan terutama dimaksudkan untuk memperkirakan besarnya debit puncak, sebagai dasar untuk menentukan debit banjir rencana dalam simulasi

keruntuhan Bendungan Tempuran. Beberapa tahapan yang dilakukan dalam rangka analisis hidrologi antara lain adalah analisis curah hujan rencana, dan analisis debit banjir rancangan.

i) Curah Hujan Rencana

Penentuan curah hujan rencana dilakukan dengan cara statistik yaitu dengan analisis frekuensi. Analisis frekuensi dimaksudkan untuk mencari hubungan antara besarnya kejadian ekstrim terhadap frekuensi kejadian dengan menggunakan distribusi probabilitas. Kejadian ekstrim dalam studi ini adalah curah hujan ekstrim yaitu curah hujan harian maksimum setiap tahun yang diukur dalam beberapa tahun.

Analisis frekuensi merupakan suatu prosedur untuk memperkirakan frekuensi dari suatu kejadian pada masa lalu atau masa yang akan datang. Analisis frekuensi digunakan untuk menentukan hujan rencana dalam berbagai periode ulang berdasarkan distribusi yang paling sesuai antara distribusi hujan secara teoritik dengan distribusi hujan secara empirik. Hujan rancangan ini digunakan untuk menentukan intensitas hujan yang diperlukan dalam perhitungan debit banjir menggunakan metode rasional.

Periode ulang adalah waktu hipotetik dimana hujan dengan suatu besaran tertentu akan disamai atau dilampauisekali dalam jangka waktu tersebut. Periode ulang $\mathrm{T}$ tahun, misal $T=50$ tahun, hujan yang diperkirakan adalah hujan 50 tahunan, mengandung pengertian bahwa hujan tersebut diharapkan disamai atau dilampaui rata-rata satu kali dalam 50 tahun. Hal ini tidak berarti bahwa hujan 50 tahunan hanya akan terjadi satu kali dalam periode 50 tahun yang berurutan, melainkan diperkirakan bahwa hujan tersebut jika dilampaui $\mathrm{k}$ kali dalam periode panjang $\mathrm{M}$ tahun akan mempunyai nilai $\mathrm{k} / \mathrm{M}$ yang kira-kira sama dengan $1 / 50$.

Probabilitas bahwa suatu kejadian akan menyamai atau lebih besar dari suatu nilai tertentu (hujandengan periode ulang $\mathrm{T}$ ) atau dengan kata lain probabilitas bahwa suatu 
kejadian atau peristiwa akan terjadi dalam satu tahun ditentukan dengan 1/T. Langkahlangkahanalisis frekuensi adalah sebagai berikut :

1) Menentukan hujan harian maksimum rerata untuk tiap-tiap tahun data.

2) Menghitung parameter statistik dari data yang telah diurutkan dari besar ke kecil, yaitu: Mean, Standard Deviation, Coefficient of Variation, Coefficient of Scewness, Coefficient of Curtosis.

3) Menentukan jenis distribusi berdasarkan parameter statistik yang ada.

4) Sifat-sifat khas dari setiap macam distribusi frekuensi adalah sebagai berikut.

a. Distribusi Normal

Ciri khas distribusi Normal adalah:

1) Skewness (Cs) $\cong 0,00$

2) Kurtosis $(\mathrm{Ck})=3,00$

3) $\operatorname{Prob} X \leq(\bar{X}-S)=15,87 \%$

4) $\operatorname{Prob} X \leq \bar{X}=50,00 \%$

5) $\operatorname{Prob} X \leq(\bar{X}+S)=84,14 \%$

b. Distribusi Log Normal

Sifat statistik distribusi Log Normal adalah:

1) $C s \cong 3 \mathrm{CV}$

2) $C s>0$

c. Distribusi Gumbel

Ciri khas statistik distribusi Gumbel adalah:

1) $C s \cong 1,396$

2) $C k \cong 5,4002$

d. Distribusi Pearson IISifat statistik distribusi ini adalah:

1) jika tidak menunjukkan sifat-sifat seperti pada ketiga distribusi di atas,

2) garis teoritik probabilitasnya berupa garis lengkung.

5) Berdasarkan jenis distribusi terpilih dihitung besaran hujan rancangan untuk kala ulang tertentu. Secara umum, persamaan garis teoritik probabilitas untuk analisis frekuensi dapat dinyatakan dengan rumus sederhana sebagai berikut:

$$
X_{T}=\bar{X}+K_{T} . S
$$

dengan:

$X_{T}=$ Hujan rancangan dengan kala ulang $T$ tahun,

$\bar{X}=$ Besaran rata-rata,

$S=$ Simpangan baku,

$K_{T}=$ Faktor frekuensi untuk kala ulang $T$ tahun.

PMP didefinisikan sebagai tinggi terbesar hujan dengan durasi tertentu yang secara meteorologis dimungkinkan bagi suatu daerah pengaliran dalam suatu waktu dalam tahun, tanpa adanya kelonggaran yang dibuat untuk trend klimatologis jangka panjang (C.D Soemarto, 1995).

Hersfield mengajukan rumus yang didasarkan atas persamaan frekuensi umum, dikembangkan oleh Chow (1951) dalam Ward dan Robinson (1990). Rumus ini mengaitkan antara besarnya PMP untuk lama waktu hujan tertentu terhadap nilai tengah $\left(X_{n}\right)$ dan standar deviasi $\left(S_{n}\right)$.

$$
P M P=X_{n}+K_{m} \cdot S_{n}
$$

Dengan:

PMP = Probable Maximum Precipitation

$\mathrm{K}_{\mathrm{m}} \quad$ = faktor pengali terhadap standar deviasi (5-20)

$\mathrm{X}_{\mathrm{n}} \quad=$ nilai tengah (mean) data hujan maksimum tahunan

$\mathrm{S}_{\mathrm{n}} \quad=$ standar deviasi data hujan maksimum tahunan

31 Analisis Keruntuhan Bendungan (DAM Break Analysis) Dalam Upaya Mitigasi Bencana (Studi Kasus di Waduk/Bendungan Tempuran (Muhamad Arifin, Muchamad Arif Budiyanto) 
Nilai Km diperoleh dari grafik di bawah ini

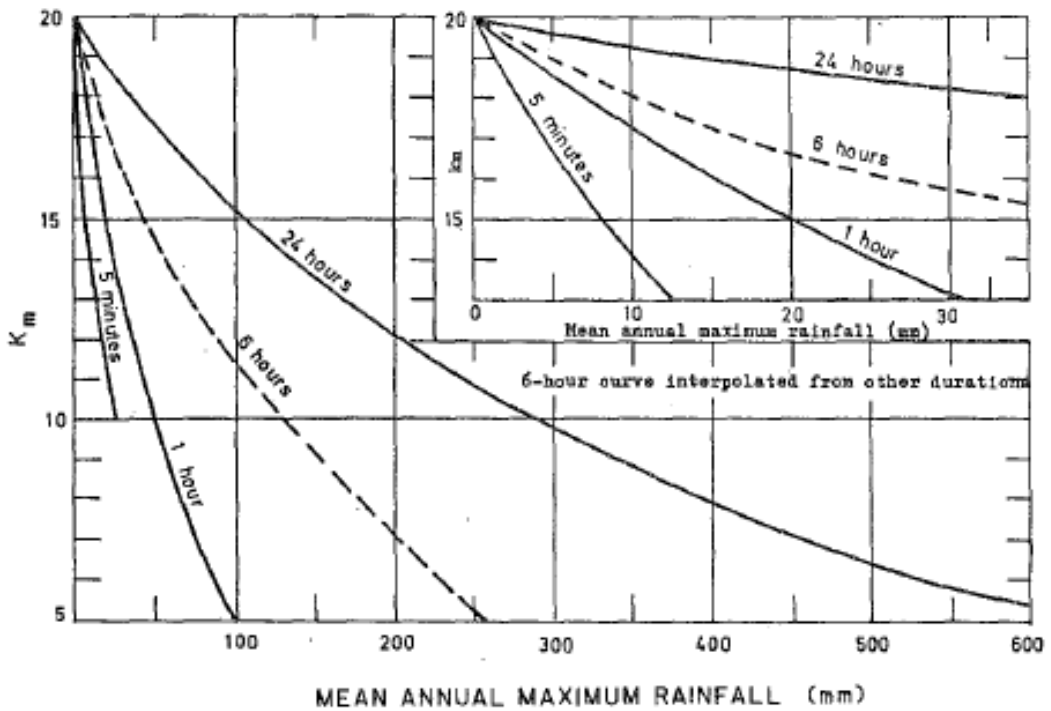

Gambar 3. Grafik Penentuan Nilai Km

Sumber: WMO 1986.

ii) Debit Banjir Rencana

Analisis debit banjir dimaksudkan untuk menentukan besaran debit banjir rencana berdasarkan data dan kondisi saat ini. Pemilihan metode analisis debit banjir rencana tergantung ketersediaan data aliran. Oleh karena data aliran tidak diperoleh debit banjir dihitung dengan menggunakan transformasi hujan menjadi aliran. Analisis debit banjir rencana dilakukan berdasarkan hujan rencana dan kondisi DAS Tempuran untuk berbagai kala ulang termasuk PMF.

Analisis banjir rancangan dilakukan dengan bantuan hidrograf satuan sintetis. Hidrograf satuan sintetis digunakan dalam analisis hidrologi dimana ketersediaan data hidrologi sangat terbatas dan tidak bisa digunakan untuk menurunkan hidrograf satuan, sehingga perlu di buat hidrograf satuan sintetis yang didasarkan pada karakteristik fisik dari sebuah DAS. Analisis banjir rencana dilakukan dengan menurunkan hidrograf satuan sintetis dengan metode HSS Snyder.

Parameter yang dikembangkan dalam metode Hidrograf Satuan Sintetis Snyder terdiri dari empat parameter yaitu waktu kelambatan, aliran puncak, waktu dasar, dan durasi standar dari hujan efektif untuk hidrograf satuan dikaitkan dengan geometri fisik dari DAS dengan hubungan berikut.

$$
\begin{aligned}
& \mathrm{T}_{\mathrm{p}}=\mathrm{C}_{\mathrm{t}}\left(\mathrm{L} \mathrm{L}_{\mathrm{c}}\right)^{0,3} \\
& \mathrm{Q}_{\mathrm{p}}=\mathrm{C}_{\mathrm{P}} \mathrm{A} / \mathrm{t}_{\mathrm{p}} \\
& \mathrm{T}=3+\left(\mathrm{t}_{\mathrm{p}} / 8\right) \\
& \mathrm{T}_{\mathrm{D}}=\mathrm{t}_{\mathrm{P}} / 5,5
\end{aligned}
$$

Apabila durasi hujan efektif $t_{r}$ tidak sama dengan durasi standar $t_{D}$, maka:

$$
\begin{aligned}
& T_{p} R=t_{p}+0,25\left(t_{r}-t_{D}\right) \\
& Q_{p} R=Q_{p} t_{p} / t_{p} R \\
& \text { dengan: }
\end{aligned}
$$$$
t_{D} \quad=\text { durasi standar dari hujan efektif (jam) }
$$$$
t_{r} \quad=\text { durasi hujan efektif (jam) }
$$

$t_{p} \quad=$ waktu dari titik berat durasi hujan efektif $t_{D}$ ke puncakhidrograf satuan (jam) 


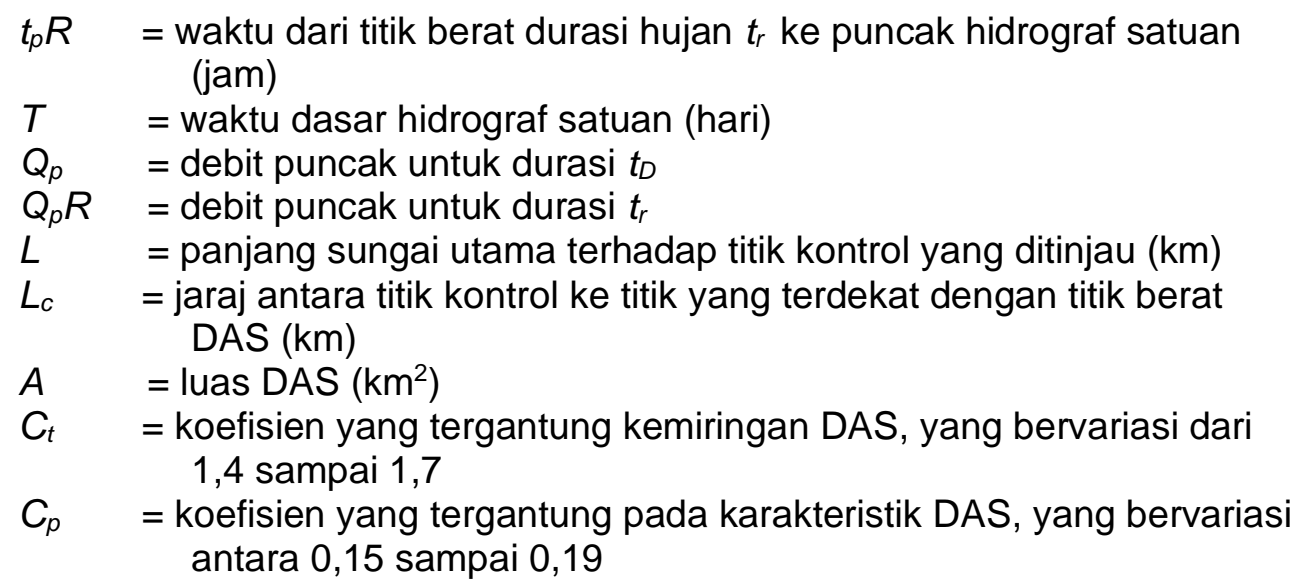

Dengan menggunakan rumus-rumus tersebut di atas dapat digambarkan hidrograf satuan. Untuk memudahkan penggambaran, berikut ini diberikan beberapa rumus:

$$
W_{50}=\frac{0,23 A^{1,08}}{Q_{p R}{ }^{1,08}} \quad W_{75}=\frac{0,13 A^{1,08}}{Q_{p R}{ }^{1,08}}
$$

Dengan $W_{50}$ dan $W_{75}$ adalah lebar unit hidrograf pada debit $50 \%$ dan $75 \%$ dari debit puncak, yang dinyatakan dalam jam. Sebagai acuan, lebar $W_{50}$ dan $W_{75}$ dibuat dengan perbandingan 1:2; dengan sisi pendek di sebelah kiri dari hidrograf satuan (Triatmodjo, 2006)

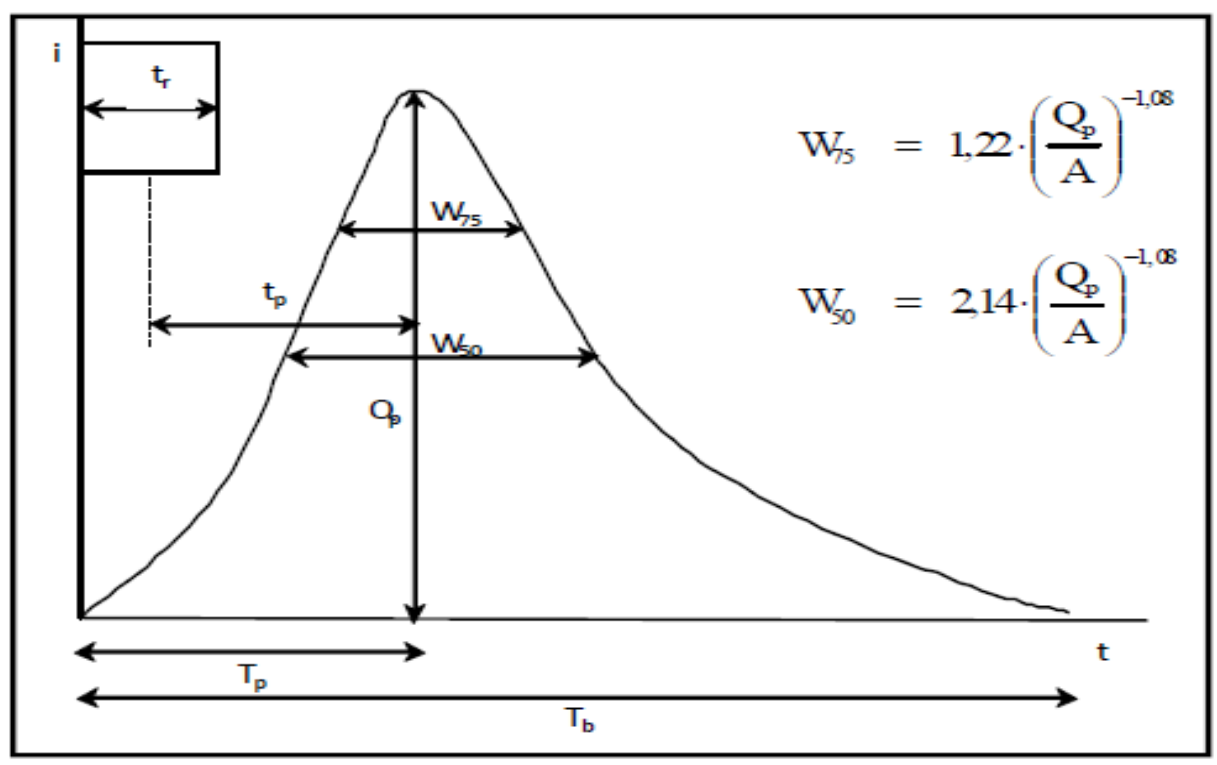

Gambar 4. Bentuk Umum HSS Snyder.

\subsection{Analisis Keruntuhan Bendungan}

Analisis keruntuhan bendungan IDam Break Analisis dimaksudkan untuk menggambarkan daerah terdampak banjir akibat keruntuhan bendungan. Input/ masukan yang diperlukan dalam analisis keruntuhan bendungan meliputi: 1)Analisis hidrologi, meliputi: penentuan Probable Maximum Flood (PMF) dan routing banjir yang keluar dari pelimpah, 2) Identifikasi Keruntuhan Bendugan meliputi Penyebab keruntuhan bendungan, Mekanisme keruntuhan bendungan, 3) Pemilihan Alat Bantu Analisis Keruntuhan Bendungan, 4) Pemetaan daerah tergenang (berbahaya).

33 Analisis Keruntuhan Bendungan (DAM Break Analysis) Dalam Upaya Mitigasi Bencana (Studi Kasus di Waduk/Bendungan Tempuran (Muhamad Arifin, Muchamad Arif Budiyanto) 


\subsubsection{Mekanisme Keruntuhan Bendungan}

Mekanisme keruntuhan bendungan pada umumnya dapat dikelompokkan menjadi 2 (dua), yaitu (1) Luapan Air di Atas Puncak Tanggul (Overtopping) dan (2) Aliran Air pada Tubuh Bendungan atau Batuan Pondasi (Piping). Overtopping adalah limpahan air melewati puncak (mercu) bendungan karena terjadinya banjir besar (berlebihan) dan/atau tidak bekerjanya pintu. Identifikasi terjadinya overtopping:

1. Kondisi elevasi air di atas maksimal (elevasi di atas mercu bangunan pelimpah),

2. Pintu macet dan atau pelimpah tersumbat,

3. Terjadi hujan deras terus menerus selama lebih dari 9 jam,

4. Penambahan tinggi muka air $>30 \mathrm{~cm} /$ hari.

Mekanisme keruntuhan bendungan yang kedua adalah akibat adanya aliran air pada tubuh bendungan atau batuan pondasi (piping). Yang dimaksud dengan piping (bocoran) adalah keadaan dimana air waduk menerobos keluar melalui lubang yang terjadi pada tubuh/pondasi bendungan yang disebabkan oleh erosi buluh yang cukup besar. Piping dapat terjadi karena adanya proses geologi yang menyebabkan terjadinya pelarutan mineral pada pondasi bendungan. Oleh karena itu pengamatan tubuh bendungan dan sekitarnya perlu dilakukan secara terus menerus agar sedini mungkin dapat segera mendeteksi bocoran pada pondasi.

Elemen kunci untuk menghitung hidrograf keruntuhan bendungan untuk bendungan yang spesifik adalah mengestimasi parameter keruntuhan bendungan yang berkaitan dengan geometri dan waktu pembentukan keruntuhan bendungan (FEMA, 2013). Parameter keruntuhan bendungan tersebut yaitu:

a. Waktu pembentukan keruntuhan adalah waktu antara keruntuhan pertama kali pada lereng hulu bendungan dan ketika keruntuhan telah mencapai geometri akhir.

b. Kedalaman keruntuhan adalah kedalaman yang diukur dari elevasi dasar keruntuhan hingga puncak keruntuhan bendungan.

c. Lebar keruntuhan adalah rata-rata lebar keruntuhan akhir, biasanya diukur pada titik tengah kedalaman keruntuhan.

d. Faktor kemiringan sisi keruntuhan adalah sudut sisi keruntuhan yang ditunjukkan sebagai $\mathrm{X}$ horisontal dan 1 vertikal $(\mathrm{XH}: 1 \mathrm{~V})$

Model empiris sederhana bentuk keruntuhan bendungan trapesoidal merupakan bentuk yang sering diaplikasikan (Fread and Harbaugh, 1973; Fread, 1984; U.S. Army Corps of Engineers, 1978; dan Brunner, 2002 dalam Froehlich, 2008). Gambar 7.1 menunjukkan perkiraan dimensi akhir keruntuhan bendungan dengan bentuk trapesoidal.

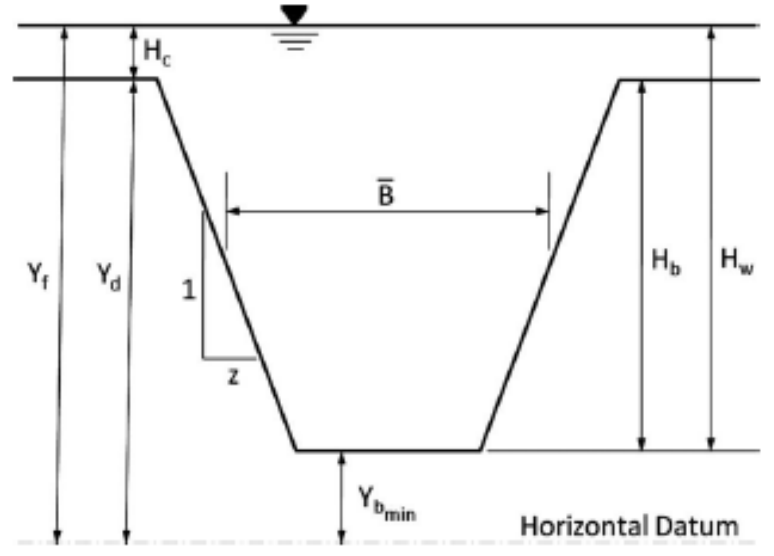

Keterangan

a. $\mathrm{H}_{\mathrm{b}}=$ tinggi bendungan,

b. $\bar{B}=$ lebar rata-rata,

c. $z=$ rasio kemiringan lereng 1: $z$ (vertikal: horisontal).

d. Keruntuhan bendungan dimulai ketika elevasi muka tampungan mencapai elevasi keruntuhan $\left(\mathrm{y}_{\mathrm{f}}\right)$.

\section{Gambar 5. Perkiraan Dimensi Akhir Bentuk Keruntunan Bendungan Sumber: Froehlich (2008)}

Analisis Keruntuhan Bendungan (DAM Break Analysis) Dalam Upaya Mitigasi Bencana (Studi Kasus di Waduk/Bendungan Tempuran (Muhamad Arifin, Muchamad Arif Budiyanto) 
Persamaan untuk mencari parameter-parameter keruntuhan bendungan telah dikembangkan oleh banyak peneliti. Rangkuman persamaan parameter keruntuhan bendungan telah diringkas oleh Wu (2011) seperti yang ditunjukkan pada tabel 1Tabel 1 Rangkuman Persamaan Parameter Keruntuhan Bendungan

\begin{tabular}{|c|c|}
\hline Peneliti & Persamaan \\
\hline Kirkpatrick (1977) & $\mathrm{Q}_{p}=1,268\left(\mathrm{~h}_{\mathrm{w}}+0,3\right)^{2,5}$ \\
\hline SCS (1981) & $Q_{p}=16,6\left(h_{w}\right)^{1,85}$ \\
\hline Hagen (1982) & $Q_{p}=0,54\left(h_{d} S\right)^{0,5}$ \\
\hline Singh dan Snorrason (1984) & $Q_{p}=1,77 S^{0,475}$ atau $Q_{p}=13,4\left(h_{d}\right)^{1,89}$ \\
\hline $\begin{array}{l}\text { MacDonald and Langride- } \\
\text { Monopolis (1984) } \\
\text { Costa (1985) }\end{array}$ & $\begin{array}{l}V_{\text {er }}=0,0261\left(V_{w} h_{w}\right)^{0,769}(\text { timbunan tanah) } \\
V_{\text {er }}=0,00348\left(V_{w} h_{w}\right)^{0,852} \text { (nontimbunan tanah) } \\
T_{f}=0,0179\left(V_{e r}\right)^{0,364} ; Q_{p}=1,154\left(V_{w} h_{w}\right)^{0,41} \\
Q_{p}=0,981\left(h_{d} S\right)^{0,42}\end{array}$ \\
\hline Evan & $\mathrm{Q}_{\mathrm{p}}=0,72\left(\mathrm{~V}_{\mathrm{w}}\right)^{0,53}$ \\
\hline USBR (1988) & $B_{\text {avg }}=3 h_{w} ; t_{f}=0,011 B_{\text {avg }} ; Q_{p}=19,1\left(h_{w}\right)^{1,85}$ \\
\hline Von Thun and Gilette (1990) & $\begin{array}{l}B_{\text {avg }}=2,5 h_{w}+C_{b} \\
t_{f}=B_{\text {avg }} /\left(4 h_{w}\right) \text { (erosion resistant) } \\
t_{f}=B_{\text {avg }} /\left(4 h_{w}+61\right) \text { (highly erodible) } \\
Q_{p}=0,607\left(V_{w}\right)^{0,295}\left(h_{w}\right)^{1,24}\end{array}$ \\
\hline Froechlich (1995b) & $B_{\text {avg }}=0,1803 \mathrm{~K}_{\mathrm{o}}\left(\mathrm{V}_{\mathrm{w}}\right)^{0,32}\left(\mathrm{~h}_{\mathrm{b}}\right)^{0,19} ; \mathrm{t}_{f}=0,00254\left(\mathrm{~V}_{\mathrm{w}}\right)^{0,53}\left(\mathrm{~h}_{\mathrm{b}}\right)^{-0,9}$ \\
\hline Walder and O'Connor (1997) & $Q_{p}=f\left(V_{w}\right.$, relative erodibility $)$ \\
\hline Xu dan Zhang (2009) & $\mathrm{B}, \mathrm{Q}_{\mathrm{p}}, \mathrm{tf}_{\mathrm{f}}=\mathrm{f}\left(\mathrm{V}_{\mathrm{w}}, \mathrm{h}_{\mathrm{w}}\right.$, erodibility $)$ \\
\hline Pierce et al. (2010) & $Q_{p}=0,0176(V h)^{0,606}$ atau $Q_{p}=0,0381 V^{0,475} h^{1,09}$ \\
\hline
\end{tabular}

Keterangan: $B=$ lebar keruntuhan; $B_{\text {avg }}=$ rata-rata lebar keruntuhan $(m) ; C_{b}=$ faktor sebagai fungsi dari volume tampungan; $h=$ tinggi air di belakang bendungan; $h_{b}=$ tinggi keruntuhan $(m)$; $h_{d}=$ tinggi bendungan $(m) ; h_{w}=$ tinggi air di atas keruntuhan $(m) ; K_{0} 1 / 41: 4$ untuk overtopping and 1.0 untuk piping; $Q_{p}=$ debit puncak $(\mathrm{m} 3 / \mathrm{s}) ; \mathrm{S}=$ volume tampungan $\left(\mathrm{m}^{3}\right) ; \mathrm{t}_{\mathrm{f}}=$ waktu keruntuhan ( $\mathrm{h}$ ); $\mathrm{V}=$ volume air di belakang bendungan; $\mathrm{V}_{\mathrm{er}}=$ volume timbunan material yang tererosi $\left(\mathrm{m}^{3}\right) ; \mathrm{V}_{\mathrm{w}}=$ volume air yang melewati bagian atas keruntuhan $\left(\mathrm{m}^{3}\right)$; and $\mathrm{z}=$ koefisien kemiringan lereng sisi keruntuhan seperti terlihat pada gambar 6.1

Sumber: Wu (2011)

Selain pengunaan persamaan keruntuhan bendungan, beberapa lembaga telah mempublikasikan rentang kemungkinan nilai parameter keruntuhan bendungan seperti: lebar, kemiringan sisi, dan waktu pembentukan keruntuhan bendungan. Tabel berikut ini menunjukkan rentang kemungkinan nilai karakteristik keruntuhan bendunganyang diringkas oleh USACE (2007) dalam Gee (2009).

Tabel 2 Rentang Kemungkinan Nilai Karakteristik Keruntuhan Bendungan

\begin{tabular}{|c|c|c|c|c|}
\hline $\begin{array}{l}\text { Tipe } \\
\text { bendungan }\end{array}$ & $\begin{array}{l}\text { Rata-rata lebar } \\
\text { keruntuhan } \\
B_{\text {ave }}\end{array}$ & $\begin{array}{l}\text { Komponen } \\
\text { horisontal pada } \\
\text { lereng sisi } \\
\text { keruntuhan (H) } \\
\text { H:1V }\end{array}$ & $\begin{array}{l}\text { Waktu } \\
\text { keruntuhan } \\
\text { tf } \\
\text { (hrs) }\end{array}$ & Lembaga \\
\hline $\begin{array}{l}\text { Timbunan } \\
\text { tanah/batu }\end{array}$ & $\begin{array}{l}(0.5 \text { to } 3.0) \times \mathrm{HD} \\
(0.5 \text { to } 5.0) \times \mathrm{HD} \\
(1.0 \text { to } 5.0) \times \mathrm{HD}\end{array}$ & $\begin{array}{l}0 \text { to } 1.0 \\
0 \text { to } 1.0 \\
0 \text { to } 1.0\end{array}$ & $\begin{array}{l}0.5 \text { to } 4.0 \\
0.1 \text { to } 4.0^{*} \\
0.1 \text { to } 1.0\end{array}$ & $\begin{array}{l}\text { USACE (1980) } \\
\text { USACE (2007) } \\
\text { FERC (1988) }\end{array}$ \\
\hline
\end{tabular}

35 Analisis Keruntuhan Bendungan (DAM Break Analysis) Dalam Upaya Mitigasi Bencana (Studi Kasus di Waduk/Bendungan Tempuran (Muhamad Arifin, Muchamad Arif Budiyanto) 


\begin{tabular}{|c|c|c|c|c|}
\hline & $(2.0$ to 5.0$) \times \mathrm{HD}$ & $\begin{array}{l}0 \text { to } 1.0 \text { (slightly } \\
\text { larger) }\end{array}$ & 0.1 to 1.0 & $\begin{array}{l}\text { NWS (Fread, } \\
\text { 2006) }\end{array}$ \\
\hline $\begin{array}{l}\text { Tipe } \\
\text { bendungan }\end{array}$ & $\begin{array}{l}\text { Rata-rata lebar } \\
\text { keruntuhan } \\
\text { B }_{\text {ave }}\end{array}$ & $\begin{array}{l}\text { Komponen } \\
\text { horisontal pada } \\
\text { lereng sisi } \\
\text { keruntuhan (H) } \\
\text { H:1V }\end{array}$ & $\begin{array}{l}\text { Waktu } \\
\text { keruntuhan } \\
\text { tf } \\
\text { (hrs) }\end{array}$ & Lembaga \\
\hline $\begin{array}{l}\text { Concrete } \\
\text { Gravity }\end{array}$ & $\begin{array}{l}\text { Multiple } \\
\text { Monoliths } \\
\text { Biasanya } \leq 0.5 \mathrm{~L} \\
\text { Biasanya } \leq 0.5 \mathrm{~L}\end{array}$ & $\begin{array}{l}\text { Vertikal } \\
\text { Vertikal } \\
\text { Vertikal }\end{array}$ & $\begin{array}{l}0.1 \text { to } 0.5 \\
0.1 \text { to } 0.3 \\
0.1 \text { to } 0.2\end{array}$ & $\begin{array}{l}\text { USACE (2007) } \\
\text { FERC } \\
\text { NWS }\end{array}$ \\
\hline $\begin{array}{l}\text { Concrete } \\
\text { Arch }\end{array}$ & $\begin{array}{l}\text { Entire Dam } \\
(0.8 \times L) \text { to } L \\
\text { Entire Dam } \\
(0.8 \times L) \text { to } L\end{array}$ & $\begin{array}{l}\text { Valley wall slope } \\
0 \text { to valley walls } \\
0 \text { to valley walls } \\
0 \text { to valley walls }\end{array}$ & $\begin{array}{l}\leq 0.1 \\
\leq 0.1 \\
\leq 0.1 \\
\leq 0.1\end{array}$ & $\begin{array}{l}\text { USACE (1980) } \\
\text { USACE (2007) } \\
\text { FERC } \\
\text { NWS }\end{array}$ \\
\hline $\begin{array}{l}\text { Slag/ } \\
\text { Refuse }\end{array}$ & $\begin{array}{l}(0.8 \times L) \text { to } L \\
(0.8 \times L) \text { to } L\end{array}$ & 1.0 to 2.0 & $\begin{array}{l}0.1 \text { to } 0.3 \\
\leq 0.1\end{array}$ & $\begin{array}{l}\text { FERC } \\
\text { NWS }\end{array}$ \\
\hline
\end{tabular}

Keterangan: $\mathrm{HD}=$ tinggi bendungan. $\mathrm{L}=$ panjang puncak bendungan.

Sumber: USACE (2007) dalam Gee (2009)

\subsubsection{Pemodelan Keruntuhan Bendungan}

Sebelum bendungan mengalami keruntuhan total, didahului oleh terjadinya rekahan (breaching). Rekahan adalah lubang yang terbentuk dalam tubuh bendungan pada saat runtuh. Sebenarnya mekanisme keruntuhannya tidak begitu dipahami, baik untuk bendungan urugan tanah maupun bendungan beton. Untuk meramal banjir di daerah hilir akibat keruntuhan bendungan, biasanya dianggap bahwa bendungan runtuh secara total dan secara mendadak.

Para peneliti dari gelombang banjir akibat keruntuhan bendungan seperti Ritter (1892), Schoklitich (1917), Dressler (1954), Stoker (1957) dan Barnes (1969) menganggap bahwa rekahan tersebut meruntuhkan seluruh tubuh bendungan dan terjadi secara mendadak. Sedangkan peneliti lain seperti Schoklitsch (1917) dan US Army Corps of Engineers (1960) mengakui perlunya anggapan rekahan sebagian, dibandingkan rekahan total, tetapi mereka masih menganggap bahwa rekahan terjadi secara mendadak. Asumsi rekahan total dan kejut ini digunakan dengan alasan untuk memudahkan bila diterapkan teknik matematika untuk menganalisis gelombang banjir dari keruntuhan bendungan. Asumsi asumsi ini agak cocok bila dipakai untuk bendungan beton pelengkung (concrete arch dam). Sedangkan untuk bendungan urugan maupun concrete gravity dam kurang cocok. Terdapat dua jenis rekahan yaitu rekahan karena overtopping dan rekahan karena piping.

\section{1) Rekahan Karena overtopping}

Rekahan karena overtopping disimulasikan berupa rekahan yang berbentuk segi empat, segitiga atau trapesium. Rekahan tersebut makin lama makin membesar dengan waktu secara progresif dari puncak bendungan ke bawah sampai mencapai pondasi. Aliran yang melewati rekahan diperhitungkan sebagai aliran melewati ambang lebar (broad crested weir).

Bentuk dari terminal breach ditentukan oleh parameter ( $Z$ ) yang mengidentifikasikan lereng samping dari rekahan, yaitu lereng vertikal : Z horisontal, dan parameter (b) yang disebut lebar terminal dari dasar rekahan.

Rentangan (range) dari nilai parameter lereng amping $Z$ adalah : $0<Z<2$. Nilai ini tergantung dari lereng alam dari material yang dipadatkan dan dibasahi. Bentuk-bentuk segipanjang, segitiga atau trapesium ditentukan dengan menggunakan kombinasi nilai-nilai $Z$ dan $b$. 
Lebar terminal $b$ dihubungkan dengan lebar rata-rata dari rekahan $b$, kedalaman rekahan $\mathrm{h}$ dan lereng rekahan $(\mathrm{Z})$, sedemikian rupa sehingga :

$$
b=b_{\text {bar }}-0,5 Z h_{d}
$$

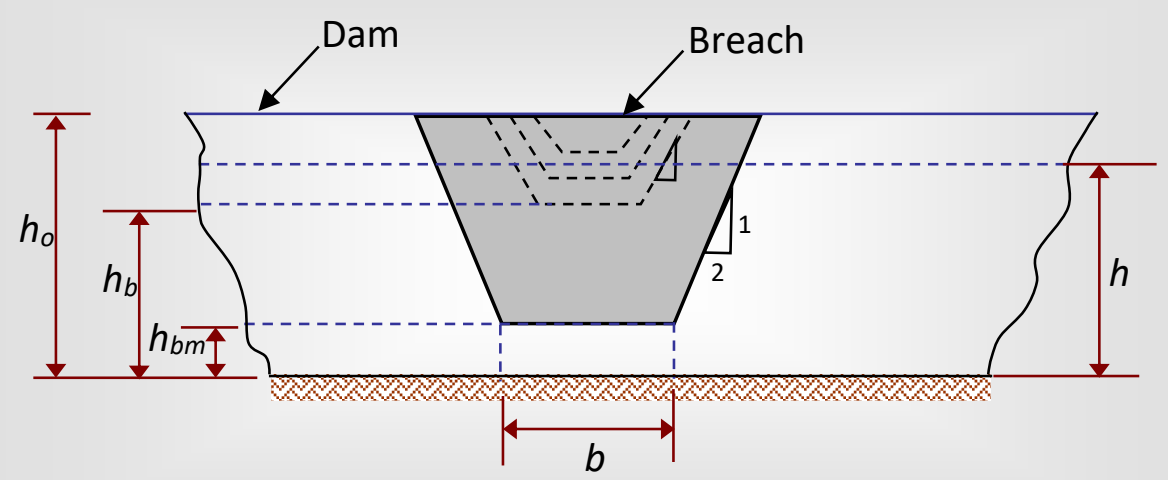

\section{Gambar 6. Formasi Perubahan Ukuran Rekahan Yang Terjadi Pada Tubuh Bendungan Akibat Overtoping}

Seperti terlihat pada gambar di atas, rekahan tersebut dimulai pada satu titik kemudian membesar dengan kecepatan linier atau nonlinier dalam selang waktu keruntuhan $\tau$ hingga tercapai lebar terminal $b$ dan dasar rekahan tererosi hingga elevasi $\mathrm{h}_{\mathrm{bm}}$ yang biasanya merupakan elevasi dasar waduk atau outlet channel.

Jika $\tau<1$ menit, lebar rekahan dimulai dengan nilai b bukan dari nol. Ini lebih menunjukkan peristiwa kehancuran karena ambruk (collapse failure) dari pada kehancuran karena erosi. Elevasi dasar rekahan di simulasikan sebagai fungsi dari waktu $(\tau)$ menurut hubungan berikut ini :

$$
h_{b}=h_{d}-\left(h_{d}-h_{b m}\right)\left(t_{b} / \tau\right)^{\rho} \text { untuk } 0<t_{b} \leq \tau
$$

dimana :

$\mathrm{h}_{\mathrm{bm}}=$ elevasi final dari dasar rekahan

$\mathrm{t}_{\mathrm{b}} \quad=$ waktu sejak mulai terjadi rekahan

$\rho \quad=$ pangkat yang menunjukkan non linieritas yang besarnya antara 1 sampai 4

Besarannya = 1 apabila kecepatan rekahan linier

Besarannya $=2$ apabila kecepatan rekahan nonlinier kuadratik.

Lebar dasar kejut (b) dari rekahan di berikan sebagai hubungan sebagai berikut :

$b_{i}=b\left(t_{b} / \tau\right)^{\rho}$ untuk $0<t_{b} \leq \tau$

$b_{i}=$ lebar kejut rekahan

Selama simulasi dari keruntuhan bendungan, formasi rekahan yang sesungguhnya dimulai bila elevasi muka air (h) melebihi suatu nilai $h_{f}$. Gambaran ini memungkinkan adanya simulasi suatu pelimpahan (overtopping) dari suatu bendungan dimana

37 Analisis Keruntuhan Bendungan (DAM Break Analysis) Dalam Upaya Mitigasi Bencana (Studi Kasus di Waduk/Bendungan Tempuran (Muhamad Arifin, Muchamad Arif Budiyanto) 
rekahannya tidak akan terbentuk sampai aliran airnya cukup besar melewati mercu bendungan

\section{2) Rekahan Karena Piping}

Keruntuhan bendungan akibat piping dapat disimulasikan dengan menentukan elevasi sumbu dari pipingnya. Ini disimulasikan sebagai rekahan lubang (orifice) berbentuk segipanjang.

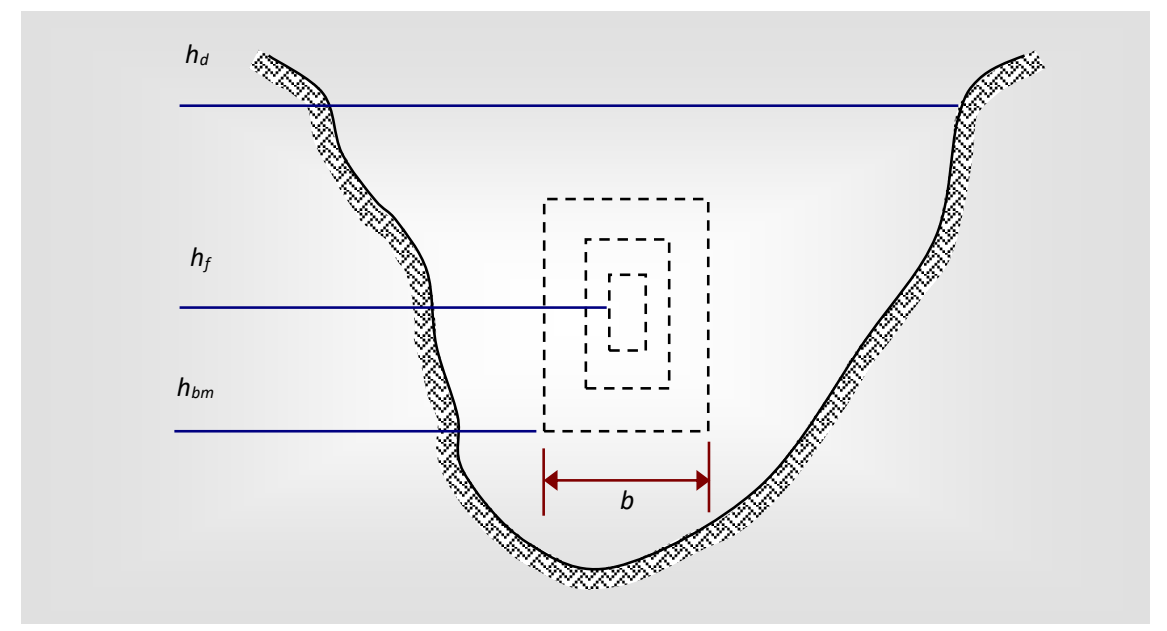

\section{Gambar 7. Formasi Perubahan Ukuran Rekahan Yang Terjadi Pada Tubuh Bendungan Akibat Piping}

Rekahan karena piping disimulasikan sebagai lubang (orifice) rekahan berbentuk segiempat yang tumbuh dengan waktu keatas dan kebawah dalam tubuh bendungan. Aliran kejut (instanteneous flow) lewat rekahan tersebut dihitung dengan rumus orifice atau sebagai ambang lebar, tergantung pada posisi muka air diwaduk dan puncak dari orifice.

Debit yang keluar dari kedua macam rekahan tersebut merupakan hidrograf banjir yang terjadi pada penampang melintang 0 (permulaan), yang harus ditelusur ke hilir disepanjang lembah sungai dengan metode "Unsteady flow".

\section{3) Pemeriksaan Parameter Rekahan}

Cara lain untuk memeriksa kebenaran parameter rekahan $\left(b_{\text {bar }}\right.$ dan $\left.\tau\right)$ adalah dengan menggunakan persamaan berikut ini :

$$
\begin{array}{ll}
\mathrm{Q}_{\mathrm{p}}{ }^{*} & =370\left(\mathrm{~V}_{\mathrm{r}} \mathrm{h}_{\mathrm{d}}\right)^{0,5} \ldots \ldots \ldots \ldots \ldots \ldots \ldots \ldots \ldots \ldots \ldots \ldots \\
\mathrm{Q}_{\mathrm{p}} & =3,1 \mathrm{~b} \text { bar }\left[\mathrm{C} /\left\{\tau+\mathrm{C} /(\mathrm{hd})^{0,5}\right\}\right]^{3} \\
\mathrm{C} & =23,4 \mathrm{As} / \mathrm{b} \text { bar } \ldots \ldots \ldots \ldots \ldots \ldots \ldots \ldots \ldots \ldots
\end{array}
$$

dalam mana :

$\mathrm{Q}_{\mathrm{p}}{ }^{*} \quad=$ debit puncak yang diharapkan lewat rekahan.

$Q_{p} \quad=$ debit puncak yang diharapkan lewat rekahan.

$\mathrm{Vr} \quad=$ volume waduk.

As = luas permukaan waduk pada puncak bendungan. 
Persamaan (4) dikembangkan oleh Hagen (1962) untuk data historik bagi 14 keruntuhan bendungan dan menghasilkan lingkungan maksimum dari seluruh 14 buah debit yang diamati.

Rumus (5) dan (6) dibuat Fread (1981) dan digunakan oleh National Weather Service dalam Simplified Dam Break Model, SMP DBK (Wetmore dan Fread, 1984).Setelah dipilih $b_{b a r}$ dan $\tau$, persamaan (5) dapat dipakai untuk menghitung $Q_{p}$ yang kemudian dapat dibandingkan dengan $Q_{p}{ }^{*}$, maka $b_{b a r}$ kecil dan/atau $\tau$ terlalu besar. Fread menemukan bahwa Pers (b) merupakan "over estimasi" debit puncak untuk tiap kegagalan dari 21 bend, (termasuk 14 kegagalan yang disebutkan sebelumnya, rata-rata 130\%.

\section{4) Simulasi Keruntuhan Bendungan}

Simulasi awal Keruntuhan Bendungan / Dam Break Analysis dilakukan dengan menggunakan program ZHONG XING HY21. Simulasi keruntuhan bendungan dilakukan berdasarkan pedoman dan standar yang berlaku di Indonesia (termasuk satuan yang dipergunakan dalam satuan metrik). Bila standar yang dimaksud belum tersedia, akan dipergunakan standar internasional yang lazim dipakai di Indonesia. Sebelum melakukan analisis keruntuhan bendungan, Konsultan mengumpulkan data yang ada dan laporan studi terdahulu yang berkaitan dengan pekerjaan ini, khususnya mengenai keadaan geografi daerah di sebelah hilir bendungan.

Analisis keruntuhan bendungan ditinjau dalam alternatif kondisi akibat piping atas pada elevasi $\pm 123 \mathrm{~m}$ dengan inflow PMF, yang diperoleh berdasarkan studi terdahulu. Selain itu penampang melintang lembah di hilir bendungan termasuk bangunan-bangunan yang berada di sungai yang perlu diperhitungkan, juga dipersiapkan terlebih dahulu. Setelah data-data tersebut diatas disiapkan, maka pekerjaan analisis untuk keruntuhan bendungan dapat mulai dilaksanakan. Adapun tahap-tahap pelaksanaan simulasi keruntuhan bendungan ini secara sistimatis dijelaskan dalam bagan yang disajikan dalam gambar dibawah ini.

Tabel 3 Tabel Parameter Data yang Dibutuhkan dalam Simulasi Zhong Xing HY21

\begin{tabular}{|c|l|}
\hline No & \multicolumn{1}{|c|}{ Parameter Data } \\
\hline 1 & Peta DEM \\
\hline 2 & Peta Rupa Bumi Indonesia \\
\hline 3 & Data teknis bendungan \\
\hline 4 & Data lengkung kapasitas waduk \\
\hline 5 & Data simulasi keruntuhan bendungan \\
\hline 6 & Data debit banjir PMF \\
\hline
\end{tabular}

39 Analisis Keruntuhan Bendungan (DAM Break Analysis) Dalam Upaya Mitigasi Bencana (Studi Kasus di Waduk/Bendungan Tempuran (Muhamad Arifin, Muchamad Arif Budiyanto) 


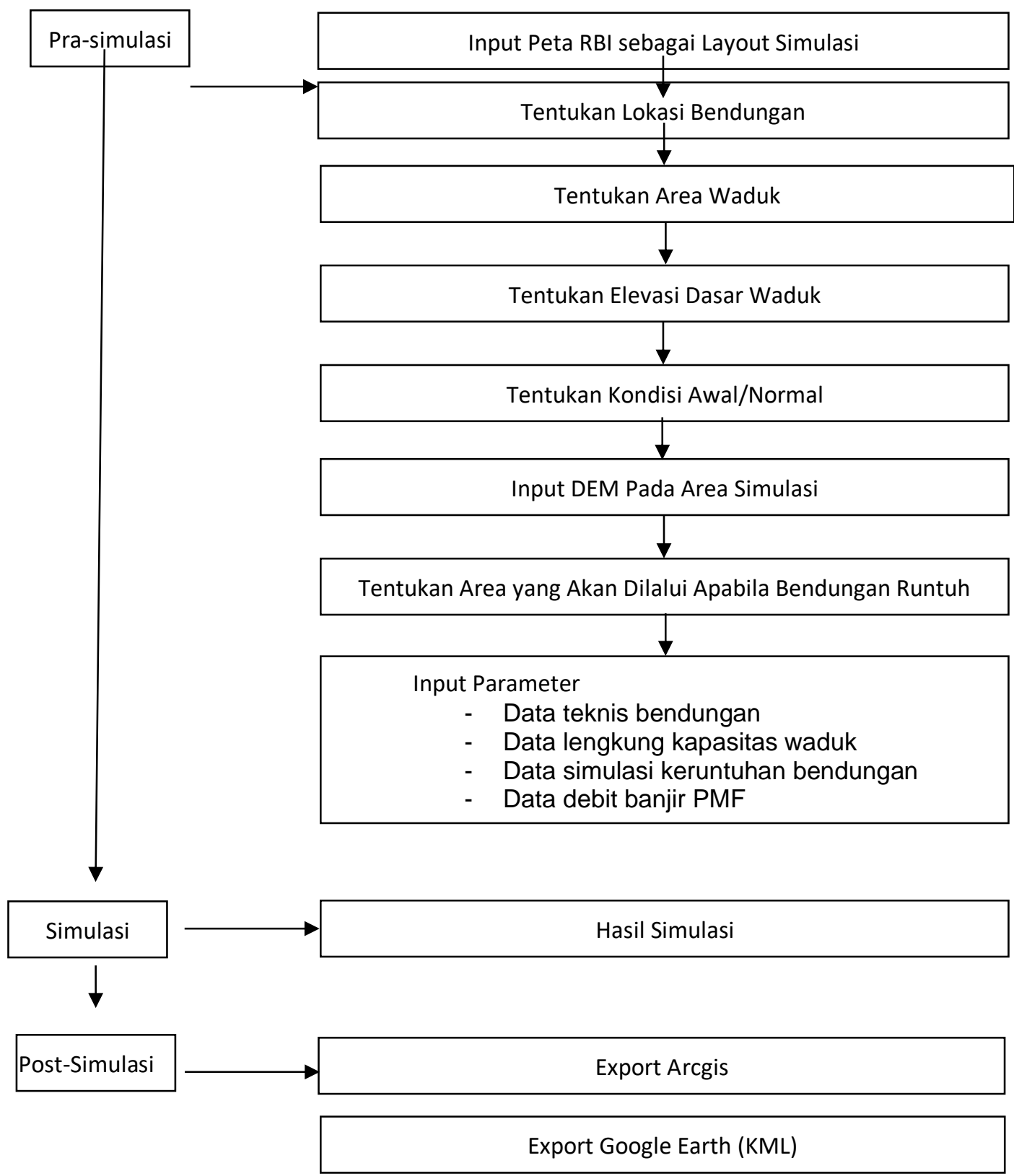

Gambar 8. Kerangka Analisis Simulasi Keruntuhan Bendungan Tempuran 


\section{METODOLOGI PENELITIAN} ini.

Diagram Alir rencana pelaksanaan Penelitian dapat dilihat dalam gambar dibawah

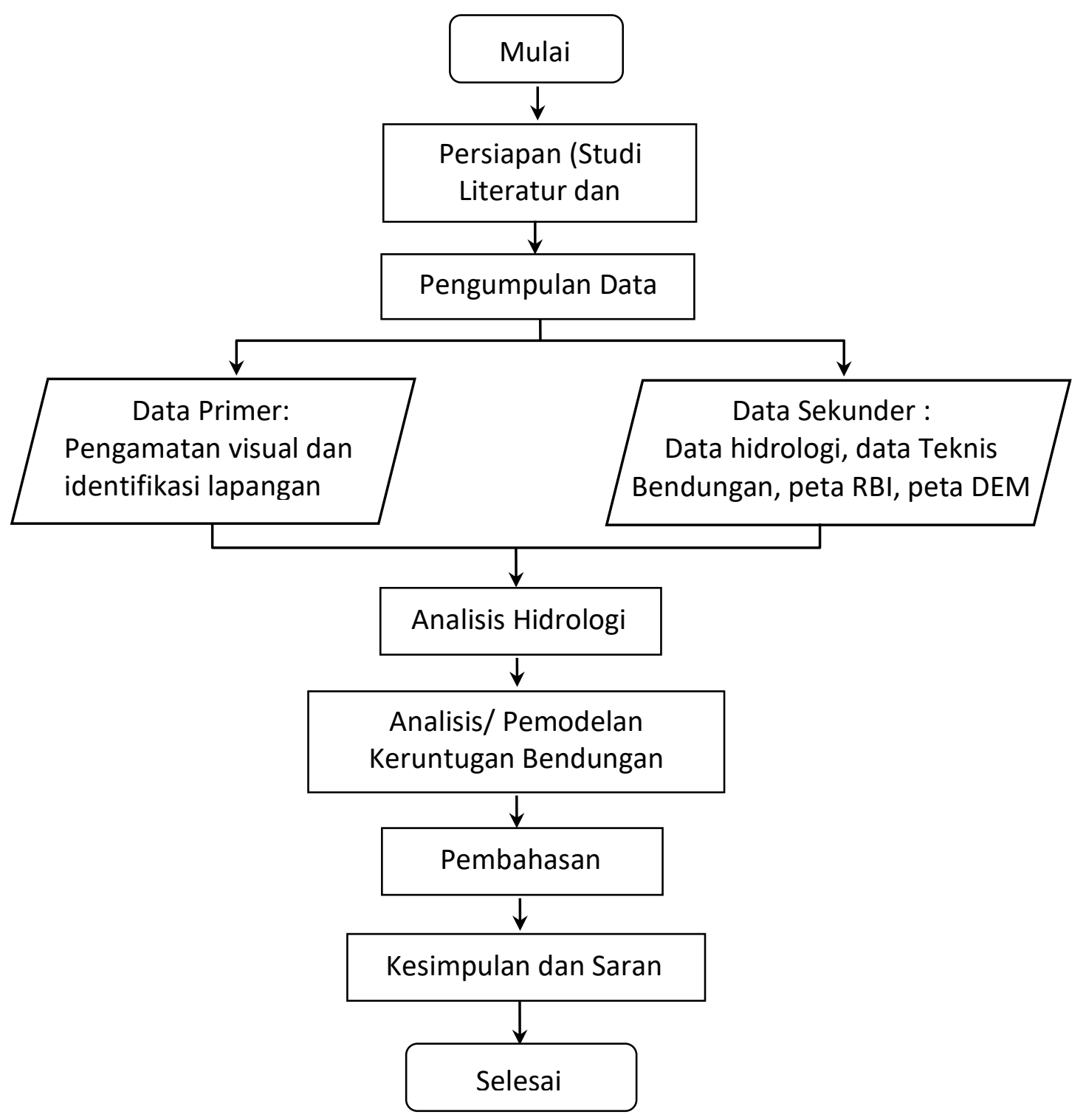

Gambar 9. Diagram Alir Penelitian

41 Analisis Keruntuhan Bendungan (DAM Break Analysis) Dalam Upaya Mitigasi Bencana (Studi Kasus di Waduk/Bendungan Tempuran (Muhamad Arifin, Muchamad Arif Budiyanto) 


\subsection{Pengumpulan Data}

Data hujan yang digunakan untuk perhitungan debit banjir berasal dari stasiun hujan tempuran seperti terlihat pada tabel berikut ini.

Tabel 4 Data Curah Hujan Maksimum Stasiun Tempuran

\begin{tabular}{|r|r|c|c|l|}
\hline No & Tahun & $\begin{array}{c}\text { Hujan } \\
\text { Tahunan }(\mathrm{mm})\end{array}$ & $\begin{array}{c}\text { Hujan Harian } \\
\text { Maksimal } \\
(\mathrm{mm})\end{array}$ & \multicolumn{1}{c|}{ Tanggal } \\
\hline 1 & 2001 & 1783 & 67 & 25 November 2001 \\
\hline 2 & 2002 & 1171 & 87 & 07 Maret 2002 \\
\hline 3 & 2003 & 708 & 50 & 15 Februari 2003 \\
\hline 4 & 2004 & 1171 & 87 & 07 Maret 2004 \\
\hline 5 & 2005 & 1129 & 50 & 17 Maret 2005 \\
\hline 6 & 2006 & 615 & 100 & 21 Maret 2005 \\
\hline 7 & 2007 & 1249 & 77 & 04 Desember 2007 \\
\hline 8 & 2008 & 1150 & 68 & 07 Maret 2008 \\
\hline 9 & 2009 & 1087 & 90 & 26 Januari 2009 \\
\hline 10 & 2010 & 2786 & 93 & 19 Oktober 2010 \\
\hline 11 & 2011 & 1079 & 50 & 01 Februari 2011 \\
\hline 12 & 2012 & 1010 & 45 & 11 Juni 2012 \\
\hline 13 & 2013 & 1636 & 91 & 04 April 2013 \\
\hline 14 & 2014 & 1318 & 47 & 18 Desember 2014 \\
\hline 15 & 2015 & 1280 & 85 & 03 Januari 2015 \\
\hline 16 & 2016 & 1805 & 91 & 16 November 2016 \\
\hline
\end{tabular}

Sumber: Balai Besar Wilayah Sungan Pemali Juwana 2017

\section{ANALISIS DAN PEMBAHASAN}

\subsection{Analisis Hidrologi}

Dengan besaran statistik hujan rerata maksimum sebesar $73,63 \mathrm{~mm}$, standar deviasi 19.53 dan konstanta harsfield $(\mathrm{km})$ sebesar 16 diperoleh besar curah hujan maksimum boleh jadi (PMP) sebesar $386,06 \mathrm{~mm}$.

Tabel 5 Hasil Analisis Hujan Rencana DAS Bendungan Tempuran
\begin{tabular}{|c|c|}
\hline Kala Ulang & $\begin{array}{c}\text { Hujan Rencana } \\
(\mathbf{m m})\end{array}$ \\
\hline 2 & 73,78 \\
\hline 5 & 90,79 \\
\hline 10 & 100,56 \\
\hline 20 & 107,71 \\
\hline 50 & 117,88 \\
\hline 100 & 123,93 \\
\hline PMP & 386,06 \\
\hline
\end{tabular}


Analisis distribusi hujan jam jaman dimaksudkan untuk mentransformasi curah hujan rancangan harian menjadi curah hujan jam-jaman. Pada umumnya data hujan yang tersedia pada suatu stasiun meteorologi adalah data hujan harian, artinya data yang tercatat secara kumulatif selama 24 jam, sedangkan analisis debit banjir rencana memerlukan masukan berupa curah hujan jam-jam an. Analisis distribusi hujan jam-jaman dihitung berdasarkan methode Alternating Block Method (ABM). Metode ini merupakan cara sederhana untuk membuat hyetograf rencana dari kurva IDF (Chow, 1988 dalam Triatmojo, 2008). Berdasarkan data hujan harian di wilayah perencanaan distribusi hujan untuk Bendungan Tempuran dapat dilihat pada Tabel 3.4 di bawah ini.

Tabel 6 Distribusi Hujan DAS Bendungan Tempuran

\begin{tabular}{|l|c|c|c|c|c|}
\hline Jam ke & 1 & 2 & 3 & 4 & 5 \\
\hline $\begin{array}{l}\text { Distribusi } \\
(\%)\end{array}$ & 8,49 & 10,66 & 58,48 & 15,20 & 7,17 \\
\hline
\end{tabular}

Sumber : Hasil Analisis

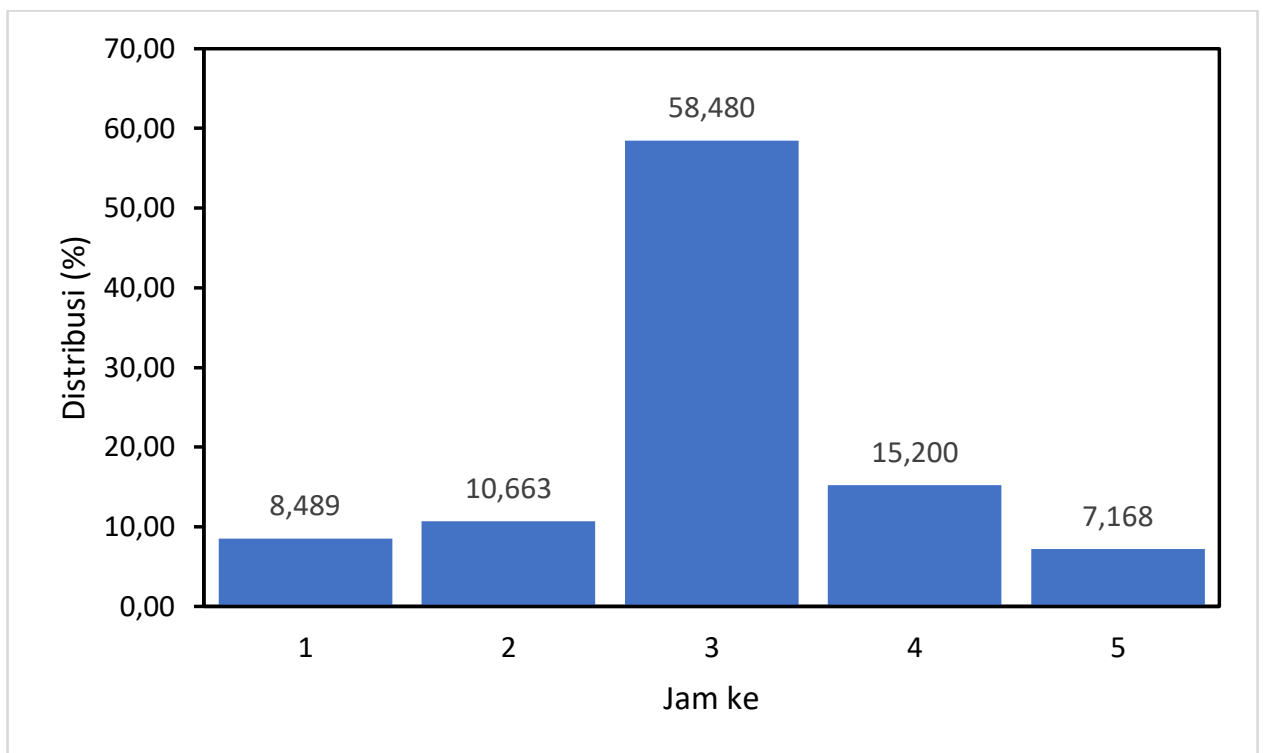

Gambar 3. 1Distribusi Hujan Jam-Jaman

Sumber : Hasil analisis

Berdasarkan distribusi hujan jam-jaman tersebut dapat dihitung distribusi hujan untuk berbagai kala ulang hujan yang disajikan pada tabel berikut ini.

Tabel 7 Distribusi Hujan Jam-Jaman DAS Bendungan Tempuran

\begin{tabular}{|c|r|r|r|r|r|r|r|r|r|}
\hline \multirow{2}{*}{ Jam } & Distribusi & \multicolumn{8}{|c|}{ Hujan Dalam Kala Ulang } \\
\cline { 3 - 11 } & \multicolumn{1}{c|}{2} & \multicolumn{1}{c|}{5} & 8.37 & 8.98 & 50 & 100 & 1000 & \multicolumn{1}{c|}{ PMP } \\
\hline 1 & 8,49 & 6.25 & 7.64 & 10.52 & 11.28 & 9.65 & 10.11 & 11.37 & 32.77 \\
\hline 2 & 10,66 & 7.85 & 9.60 & 57.69 & 61.84 & 12.13 & 12.69 & 14.28 & 41.16 \\
\hline 3 & 58,48 & 43.06 & 52.67 & 15.00 & 16.07 & 66.51 & 69.62 & 78.35 & 225.77 \\
\hline 4 & 15,20 & 11.19 & 13.69 & 7.07 & 7.58 & 17.29 & 18.10 & 20.36 & 58.68 \\
\hline 5 & 7,17 & 5.28 & 6.46 & 98.65 & 105.74 & 8.15 & 8.53 & 9.60 & 27.67 \\
\hline $\begin{array}{c}\text { Hujan } \\
\text { Rencana }\end{array}$ & 100 & 73.63 & 90.06 & 8.37 & 8.98 & 113.73 & 119.05 & 133.97 & 386.06 \\
\hline
\end{tabular}

Sumber : Hasil analisis

43 Analisis Keruntuhan Bendungan (DAM Break Analysis) Dalam Upaya Mitigasi Bencana (Studi Kasus di Waduk/Bendungan Tempuran (Muhamad Arifin, Muchamad Arif Budiyanto) 
Berdasarkan HSS metode Snyder dan Hujan Efektif dapat dihitung debit banjir rencana untuk DAS Bendungan untuk beberapa kala ulang sampai kala ulang PMF sebagai berikut.

Tabel 8 Hitungan Banjir Rancangan DAS Tempuran (SNYDER)

\begin{tabular}{|c|c|c|c|c|c|c|c|c|c|}
\hline Jam ke & \multicolumn{10}{|c|}{ Q-Kala Ulang $\left(\mathrm{m}^{3} / \mathrm{dt}\right)$} \\
\hline & 1.1 & 2 & 5 & 10 & 20 & 50 & 100 & 1000 & PMF \\
\hline 0 & 2.883 & 2.883 & 2.883 & 2.883 & 2.883 & 2.883 & 2.883 & 2.883 & 2.883 \\
\hline 1 & 2.883 & 2.883 & 2.883 & 2.883 & 2.883 & 2.883 & 2.883 & 3.374 & 15.291 \\
\hline 2 & 2.883 & 2.883 & 2.883 & 2.899 & 3.320 & 3.794 & 4.110 & 5.306 & 27.794 \\
\hline 3 & 12.868 & 21.018 & 26.371 & 29.178 & 31.755 & 34.654 & 36.587 & 42.151 & 137.257 \\
\hline 4 & 9.183 & 14.716 & 19.484 & 21.981 & 24.165 & 26.624 & 28.263 & 32.920 & 112.107 \\
\hline 5 & 5.868 & 8.551 & 11.029 & 12.326 & 13.451 & 14.718 & 15.562 & 17.955 & 68.181 \\
\hline 6 & 4.200 & 5.391 & 6.513 & 7.100 & 7.608 & 8.180 & 8.561 & 9.641 & 34.015 \\
\hline 7 & 3.447 & 3.959 & 4.445 & 4.700 & 4.920 & 5.167 & 5.332 & 5.799 & 16.591 \\
\hline 8 & 3.121 & 3.338 & 3.545 & 3.653 & 3.746 & 3.851 & 3.921 & 4.119 & 8.748 \\
\hline 9 & 2.983 & 3.074 & 3.161 & 3.206 & 3.245 & 3.289 & 3.319 & 3.402 & 5.357 \\
\hline 10 & 2.925 & 2.962 & 2.999 & 3.018 & 3.034 & 3.053 & 3.065 & 3.100 & 3.919 \\
\hline 11 & 2.900 & 2.916 & 2.931 & 2.939 & 2.946 & 2.953 & 2.959 & 2.973 & 3.315 \\
\hline 12 & 2.890 & 2.897 & 2.903 & 2.906 & 2.909 & 2.912 & 2.914 & 2.920 & 3.062 \\
\hline 13 & 2.886 & 2.889 & 2.891 & 2.893 & 2.894 & 2.895 & 2.896 & 2.898 & 2.957 \\
\hline 14 & 2.884 & 2.885 & 2.886 & 2.887 & 2.887 & 2.888 & 2.888 & 2.889 & 2.914 \\
\hline 15 & 2.883 & 2.884 & 2.884 & 2.885 & 2.885 & 2.885 & 2.885 & 2.886 & 2.896 \\
\hline 16 & 2.883 & 2.883 & 2.883 & 2.884 & 2.884 & 2.884 & 2.884 & 2.884 & 2.888 \\
\hline 17 & 2.883 & 2.883 & 2.883 & 2.883 & 2.883 & 2.883 & 2.883 & 2.883 & 2.885 \\
\hline 18 & 2.883 & 2.883 & 2.883 & 2.883 & 2.883 & 2.883 & 2.883 & 2.883 & 2.884 \\
\hline 19 & 2.883 & 2.883 & 2.883 & 2.883 & 2.883 & 2.883 & 2.883 & 2.883 & 2.883 \\
\hline 20 & 2.883 & 2.883 & 2.883 & 2.883 & 2.883 & 2.883 & 2.883 & 2.883 & 2.883 \\
\hline 21 & 2.883 & 2.883 & 2.883 & 2.883 & 2.883 & 2.883 & 2.883 & 2.883 & 2.883 \\
\hline 22 & 2.883 & 2.883 & 2.883 & 2.883 & 2.883 & 2.883 & 2.883 & 2.883 & 2.883 \\
\hline 23 & 2.883 & 2.883 & 2.883 & 2.883 & 2.883 & 2.883 & 2.883 & 2.883 & 2.883 \\
\hline 24 & 2.883 & 2.883 & 2.883 & 2.883 & 2.883 & 2.883 & 2.883 & 2.883 & 2.883 \\
\hline 25 & 2.883 & 2.883 & 2.883 & 2.883 & 2.883 & 2.883 & 2.883 & 2.883 & 2.883 \\
\hline$S 4$ & & & & & & & \\
\hline
\end{tabular}

Sumber: Hasil Analisis 


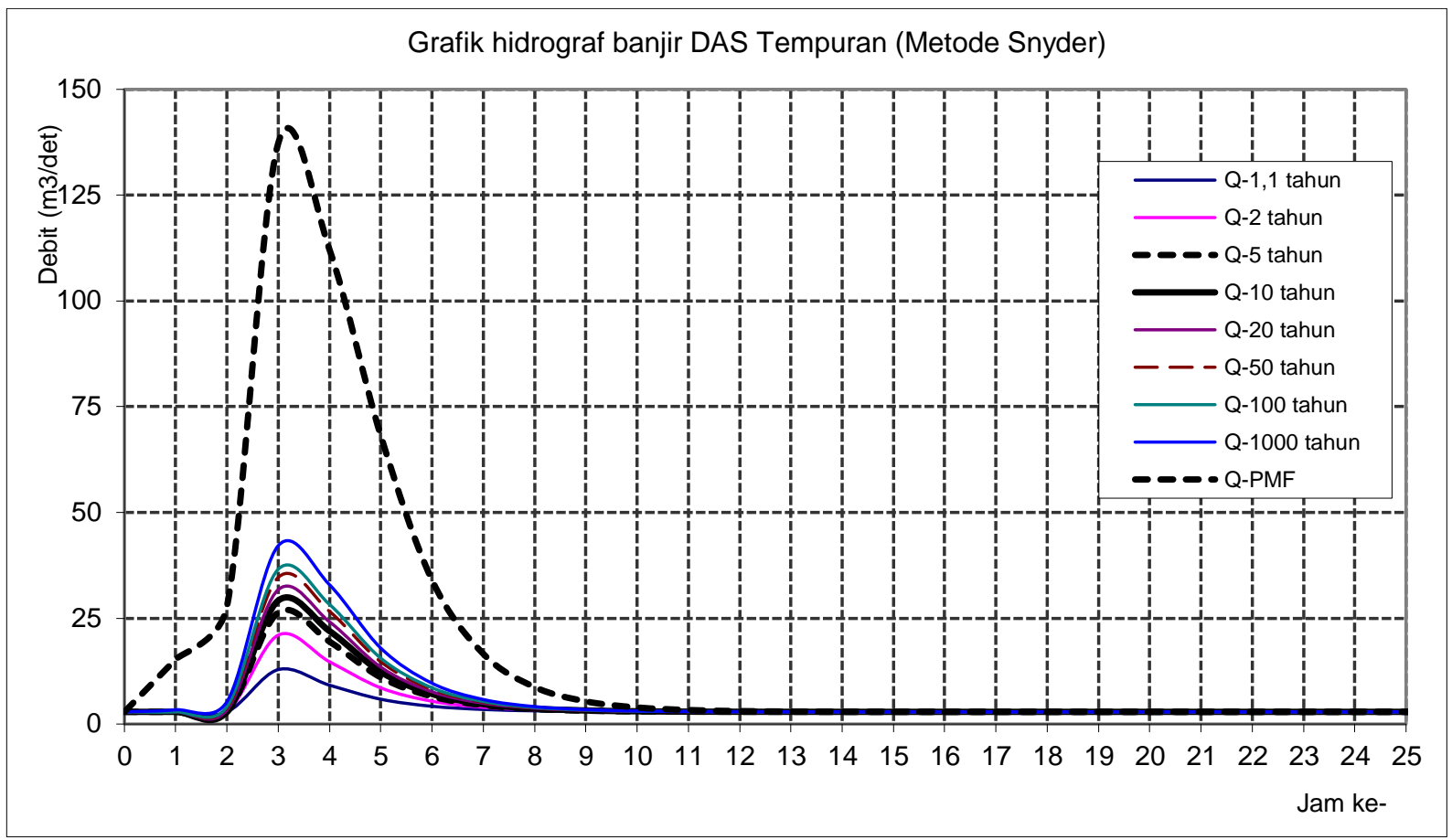

\section{Gambar 3. 2 Hidrograf Banjir Beberapa Kala Ulang DAS Tempuran Metode Snyder} Sumber: Hasil Analisis

\subsection{Analisis Keruntuhan Bendungan}

Untuk menjalankan program Zhong Xing HY21 guna mendapatkan hasil analisis kehancuran bendungan, diperlukan data-data untuk menunjang analisis tersebut. Adapun secara garis besar data-data utama dan skenario yang digunakan adalah seperti dalam tabel berikut ini.

Tabel 9 Analisis Keruntuhan Bendungan Skenario Muka Air Waduk Setinggi Banjir Desain, Dimana Inflow Hidrograf Sama Dengan Banjir Rencana

\begin{tabular}{|c|c|c|}
\hline Skenario & $\begin{array}{l}\text { Piping Atas } \\
\text { (Skenario 1) }\end{array}$ & Satuan \\
\hline $\begin{array}{l}\text { Elevasi Puncak } \\
\text { Bendungan }\end{array}$ & 123 & meter \\
\hline Upper Boundary & As Bendungan & \\
\hline Lower Boundary & - & \\
\hline Panjang Bendungan & 515 & meter \\
\hline El. Muka Air & $\begin{array}{c}122.726 \text { (MAN } \\
\text { Banjir Hasil } \\
\text { Routing) }\end{array}$ & meter \\
\hline Lebar Spillway & 15.5 & meter \\
\hline El. Puncak Spillway & 120.5 & meter \\
\hline $\begin{array}{l}\text { El. Muka Air Mulai Runtuh } \\
\text { (H_FAIL) }\end{array}$ & 122.726 & meter \\
\hline $\begin{array}{l}\text { El. Final Dasar Keruntuhan } \\
(\text { H_BM })\end{array}$ & 113 & meter \\
\hline $\begin{array}{l}\text { Lebar Rekahan Rata-rata } \\
\text { (B BAR) }\end{array}$ & 40 & meter \\
\hline
\end{tabular}

45 Analisis Keruntuhan Bendungan (DAM Break Analysis) Dalam Upaya Mitigasi Bencana (Studi Kasus di Waduk/Bendungan Tempuran (Muhamad Arifin, Muchamad Arif Budiyanto) 


\begin{tabular}{||l|c|c||}
\hline \multicolumn{1}{|c|}{ Skenario } & Piping Atas & \multirow{2}{*}{ Satuan } \\
\cline { 2 - 2 } & (Skenario 1) & \\
\hline $\begin{array}{l}\text { Waktu Keruntuhan } \\
\text { (TIME_BF) }\end{array}$ & 5400 & \multirow{2}{*}{ detik } \\
\hline El. Pusat Piping (H_PIPE) & 122.726 & meter \\
\hline$Q_{\text {inflow PMF (Snyder) }}$ PM & 137,257 & $\mathrm{~m}^{3} / \mathrm{dt}$ \\
\hline
\end{tabular}

Sumber: Hasil Analisis

Hasil keluaran / output dari analisis keruntuhan bendungan adalah peta banjir sebagai dasar acuan untuk mengetahui sampai sejauh mana dampak banjir yang di timbulkan akibat keruntuhan bendungan tersebut. Dari hasil analisis keruntuhan bendungan dengan Zhong Xing-HY21 dapat digambarkan peta banjir akibat keruntuhan bendungan. Peta genangan dimaksudkan untuk memberi keterangan mengenai lokasi yang akan terkena bahaya banjir, sebagai akibat keruntuhan bendungan. Berdasarkan peta genangan ini, proses pemberitahuan (peringatan) kepada penduduk dan prosedur pengungsian bagi penduduk yang terkena resiko oleh Pemerintah Daerah setempat dapat dilaksanakan secara terkoordinasi. Pada tahap simulasi peta genangan dibuat berdasarkan peta google Earth, yang menunjukkan peta genangan banjir hasil keluaran / output dari Program ZhongXing-HY21 untuk semua kondisi keruntuhan bendungan.

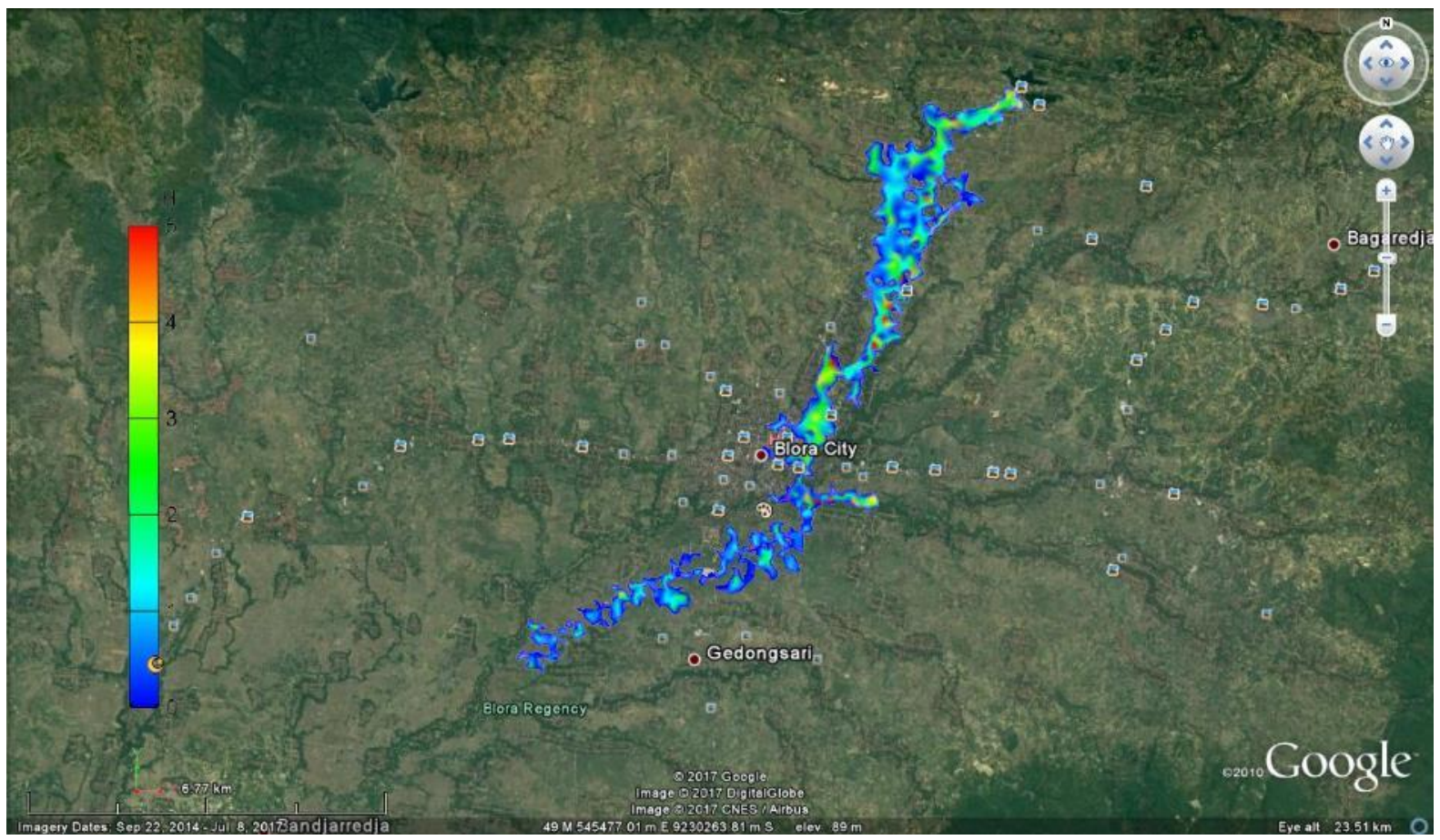

\section{Gambar 4. 1 Peta Banjir Akibat Keruntuhan Bendungan Tempuran skenario Muka Air Waduk Setinggi Banjir Desain, Dimana Inflow Hidrograf Sama Dengan Banjir Rencana dan Keruntuhan Bendungan Akibat Piping Atas.}

\subsection{Pembahasan}

Dari hasil analisis simulasi pemodelan keruntuhan bendungan Tempuran yang sudah di plotkan ke dalam Peta Rupa Bumi Indonesia, dapat diketahui wilayah yang terkena dampak banjir akibat keruntuhan Bendungan Tempuran. Disamping itu juga bisa diketahui berapa waktu yang diperlukan air Banjir untuk sampai ke masing-masing wilayah sesuai dengan jarak dan kondisi topografi di wilayah tersebut.

Untuk lebih jelasnya secara rinci wilayah-wilayah yang terkena dampak dapat dilihat dalam table berikut ini. 
Tabel 10 Wilayah Terdampak Banjir, Jarak dari Bendungan, Kedalaman Banjir, dan Wantu Tiba Banjir

\begin{tabular}{|c|c|c|c|c|c|c|}
\hline \multirow{2}{*}{ No } & \multicolumn{3}{|c|}{ Daerah Terkena Resiko } & \multirow{2}{*}{$\begin{array}{l}\text { Jarak dari } \\
\text { Bendungan } \\
(\mathrm{Km})\end{array}$} & \multirow{2}{*}{$\begin{array}{c}\text { Kedalama } \\
\text { n Banjir } \\
\text { (meter) }\end{array}$} & \multirow{2}{*}{$\begin{array}{l}\text { Waktu } \\
\text { Tiba } \\
\text { Sampai } \\
\text { Lokasi } \\
\text { (Jam) }\end{array}$} \\
\hline & Desa & Kecamatan & Kabupaten & & & \\
\hline 1 & Tempuran & Kota Blora & Blora & 0,120 & $\begin{array}{c}0,00- \\
2,00\end{array}$ & 0,25 \\
\hline 2 & Sendangharjo & Kota Blora & Blora & 0,294 & $\begin{array}{c}0,00- \\
2,00\end{array}$ & 1,50 \\
\hline 3 & Ngadipurwo & Kota Blora & Blora & 1,127 & $\begin{array}{c}0,00- \\
2,00\end{array}$ & 1,74 \\
\hline 4 & Purwosari & Kota Blora & Blora & 2,040 & $\begin{array}{c}0,00- \\
2,00\end{array}$ & 2,00 \\
\hline 5 & Keser & Tunjungan & Blora & 3,046 & $\begin{array}{c}0,00- \\
2,00\end{array}$ & 2,05 \\
\hline 6 & Tambaksari & Kota Blora & Blora & 3,690 & $\begin{array}{c}0,00- \\
2,00\end{array}$ & 2,25 \\
\hline 7 & Patalan & Kota Blora & Blora & 3,400 & $\begin{array}{c}0,00- \\
2,00\end{array}$ & 2,50 \\
\hline 8 & Tempurejo & Kota Blora & Blora & 5,358 & $\begin{array}{c}0,00- \\
2,00\end{array}$ & 2,75 \\
\hline 9 & Karangjati & Kota Blora & Blora & 6,372 & $\begin{array}{c}0,00- \\
2,00\end{array}$ & 3,50 \\
\hline 10 & Tegalgunung & Kota Blora & Blora & 7,579 & $\begin{array}{c}0,00- \\
0,60\end{array}$ & 3,70 \\
\hline 11 & Tempelan & Kota Blora & Blora & 8,113 & $\begin{array}{c}0,00- \\
0,60\end{array}$ & 3,80 \\
\hline 12 & Bangkle & Kota Blora & Blora & 7,784 & $\begin{array}{c}0,00- \\
2,00\end{array}$ & 4,0 \\
\hline 13 & Kedungjenar & Kota Blora & Blora & 8,444 & $\begin{array}{c}0,00- \\
0,60\end{array}$ & 4,50 \\
\hline 14 & Beran & Kota Blora & Blora & 8,762 & $\begin{array}{c}0,00- \\
0,60\end{array}$ & 5,20 \\
\hline 15 & Kamolan & Kota Blora & Blora & 9,912 & $\begin{array}{c}0,00- \\
0,60\end{array}$ & 6,00 \\
\hline
\end{tabular}

Sumber : Hasil Analisis

\section{KESIMPULAN DAN SARAN}

\subsection{Kesimpulan}

Setelah dilakukan analisis dan pembahasan dari penelitian ini beberapa kesimpulan yang dapat diambil diantaranya adalah sebagai berikut ini :

a. Hasil analisis hidrologi dengan data curah hujan di Stasiun Hujan Tempuran diperoleh besar curah hujan maksimum (PMP) sebesar 386,06 mm

b. Analisis debit banjir rancangan (metode Snyder) dengan kala ulang PMF (probably maximum flood) diperoleh debit puncak Qinflow sebesar $137.257 \mathrm{~m}^{3} /$ det.

c. Dari hasil pemodelan simulasi keruntuhan Bendungan Tempuran, dampak banjir yang ditimbulkan mencapai jarak terjauh 9,912 km di desa Kamolan.

d. Tinggi genangan di wilayah terdampak bervariasi sesuai dengan kondisi topografi antara 0,6 meter s.d 2,00 meter.

\subsection{Saran}

Sesuai dengan maksud dan tujuan dari penelitian ini beberapa saran/ rekomendasi yang dapat penyusun sampaikan sebagai berikut ini.

a. Perlu di lakukan analisis hidrologi dengan menggunakan metode lain sebagai pembanding hasil debit banjir rancangan dan juga perlu adanya pemodelan lebih lanjut dengan menggunakan software/perangkat lunak lainya seperti HEC RAS sebagai pembanding hasilnya.

47 Analisis Keruntuhan Bendungan (DAM Break Analysis) Dalam Upaya Mitigasi Bencana (Studi Kasus di Waduk/Bendungan Tempuran (Muhamad Arifin, Muchamad Arif Budiyanto) 
b. Perlu di buat system peringatan dini/early warning system yang komprehensif dan terintegrasi sehingga bisa sebagai acuan dasar tindakan mitigasi bencana akibat keruntuhan dari bendungan tersebut.

c. Perlu dilakukan tindak lanjut sebagai upaya untuk mitigasi bencana di wilayah terdampak secara sistematis mulai dengan penentuan titik kumpul, penentuan jalur evakuasi sampai dengan penentuan lokasi-lokasi pengungsian yang berada di wilayah yang berada di luar area terdampak.

d. Perlu adanya tindak lanjut di berupa sosialisasi kepada masuarakat terutama di wilayah terdampak mengenai resiko dan Tindakan yang perlu dilakukan dalam upaya mitigasi bencana.

\section{DAFTAR PUSTAKA}

Arif Budiyanto, Muchamad, 2017, Penelusuran Banjir Sungai Luk Ulo Akibat Perubahan Tutupan Lahan, Jurnal Geografi: Media Informasi Pengembangan dan Profesi Kegeografian, Jilid 14 No.1 Hal 26-39, Semarang

Arif Budiyanto, Muchamad, 2018, Penelusuran Waktu Perjalanan Banjir Dari Hulu Ke Hilir Sungai Code Sebagai Pertimbangan Early Warning Sistem, Jurnal Teknik Sipil, Jilid 13 No.1 Hal 41-52, Yogyakarta

Calvin, V. D., 1980, Handbook of Applied Hidraulics, McGraw Hill, New York

Chow. V. T., 1992, Open Chanel Hidraulics, Erlangga, Jakarta

Linsley. R. K., Franzini. J. B., 1979 Water Resources Engineering $3^{\text {rd }}$ Edition, McGraw Hill, New York

Loebis. J., 1992, Banjir Rencana Untuk Bangunan Air, Departemen Pekerjaan Umum, Jakarta

Sosrodarsono, B., 1977, Bendungan Type Urugan, Pradnya Paramita, Jakarta

Sriharto BR, 1993, Analisis Hidrologi, PT. Gramedia Pustaka Utama, Jakarta

Sriharto BR, 2000, Hidrologi: Teori, Masalah, Penyelesaian, Nafiri offset, Yogyakarta

Sudjarwadi, 1988, Teknik Sumber Daya Air, Pusat Antar Universitas-Universitas Gadjah Mada, Yogyakarta

Triatmodjo. B., 1995, Hidrolika II, Beta Offset, Yogyakarta

Triatmodjo. B., 2008, Hidrologi Terapan, Beta Offset, Yogyakarta 